\title{
Modified Method for Estimating Petroleum Source-Rock Potential Using Wireline Logs, With Application to the Kingak Shale, Alaska North Slope
}

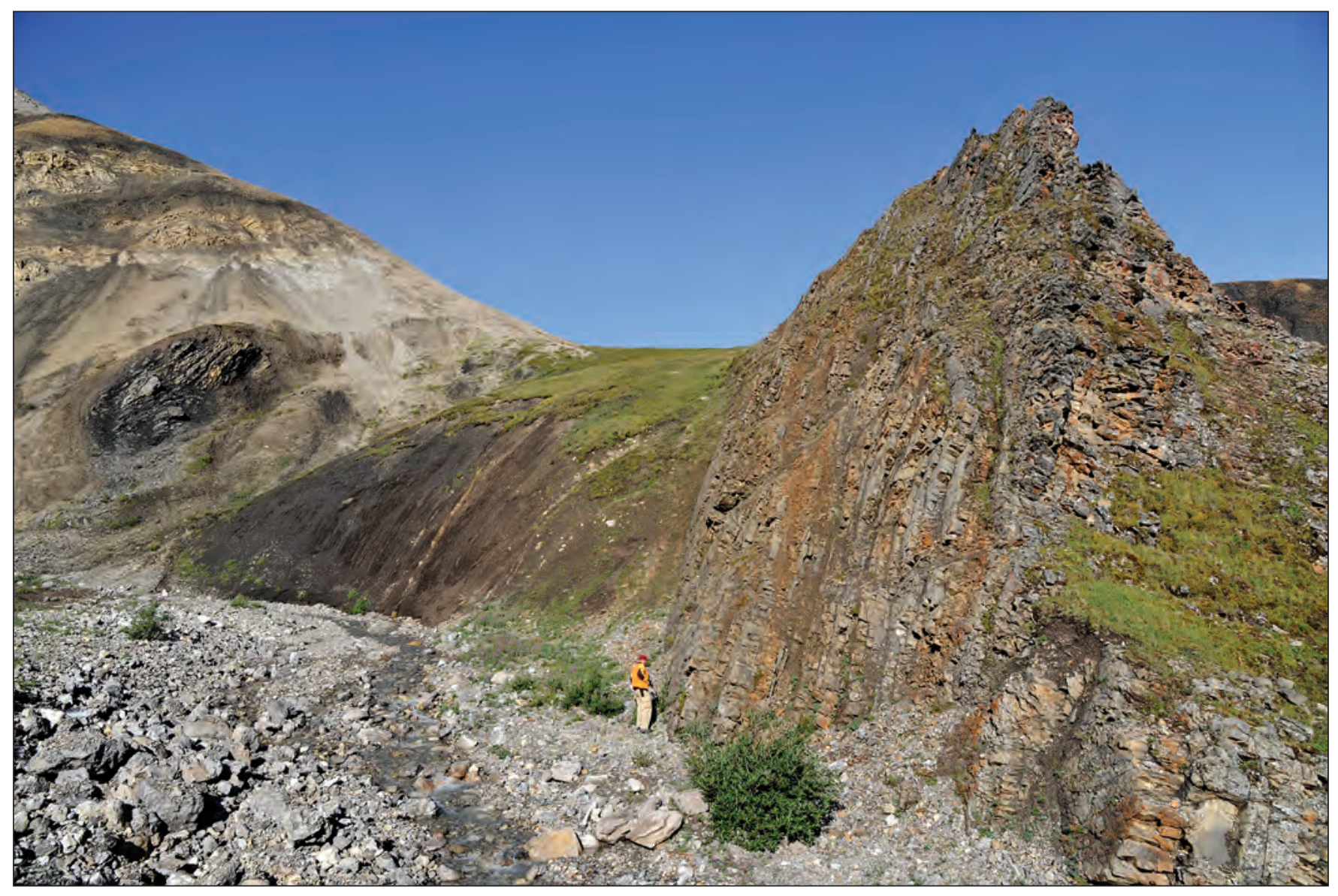

Scientific Investigations Report 2016-5001 
Cover. Outcrop along Hue Creek at the northern front of the Shublik Mountains, northeast Brooks Range. A geologist examines the steeply dipping, overturned contact between the Jurassic Kingak Shale (left-center) and Lower Cretaceous Kemik Sandstone (right). The light-colored rocks (upper left) are Proterozoic Katakturuk Dolomite, thrust northward over the Kingak Shale. The Kingak-Kemik contact is the Lower Cretaceous unconformity. Photograph by David W. Houseknecht, U.S. Geological Survey. 


\section{Modified Method for Estimating Petroleum Source-Rock Potential Using Wireline Logs, With Application to the Kingak Shale, Alaska North Slope}

By William A. Rouse and David W. Houseknecht

Scientific Investigations Report 2016-5001 


\title{
U.S. Department of the Interior SALLY JEWELL, Secretary
}

\section{U.S. Geological Survey Suzette M. Kimball, Director}

\author{
U.S. Geological Survey, Reston, Virginia: 2016
}

For more information on the USGS - the Federal source for science about the Earth, its natural and living resources, natural hazards, and the environment—visit http://www.usgs.gov or call 1-888-ASK-USGS.

For an overview of USGS information products, including maps, imagery, and publications, visit http://www.usgs.gov/pubprod/.

Any use of trade, firm, or product names is for descriptive purposes only and does not imply endorsement by the U.S. Government.

Although this information product, for the most part, is in the public domain, it also may contain copyrighted materials as noted in the text. Permission to reproduce copyrighted items must be secured from the copyright owner.

Suggested citation:

Rouse, W.A., and Houseknecht, D.W., 2016, Modified method for estimating petroleum source-rock potential using wireline logs, with application to the Kingak Shale, Alaska North Slope: U.S. Geological Survey Scientific Investigations Report 2016-5001, 40 p., http://dx.doi.org/10.3133/sir20165001.

ISSN 2328-0328 (online) 


\section{Contents}

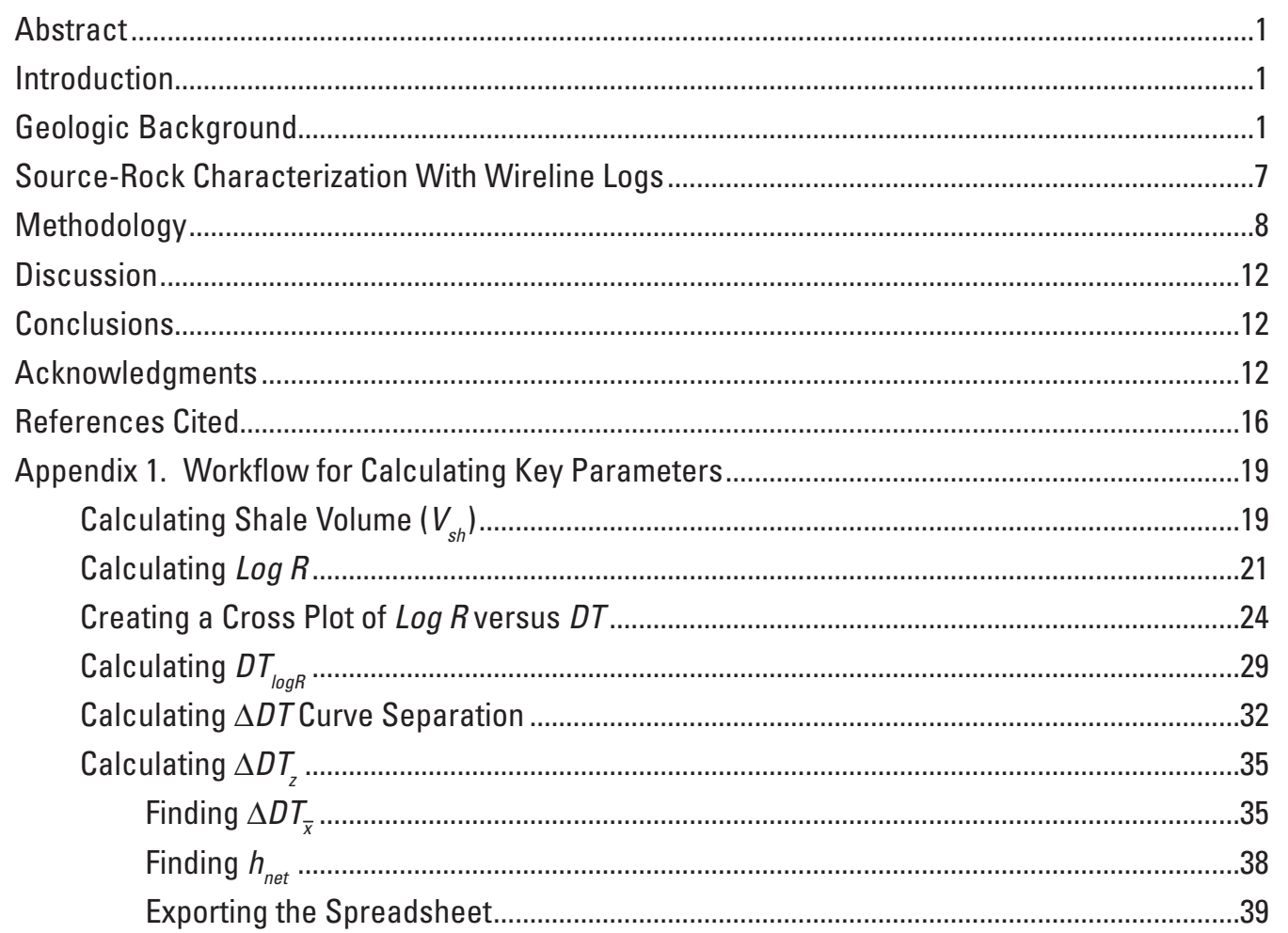




\section{Figures}

1. Diagram showing generalized chronostratigraphy for the Alaska North Slope

2. Map of northern Alaska showing areas of inferred source-rock quality in the Kingak Shale and outlines of shale-oil and shale-gas assessment units...

3. Schematic summary of inferred depositional sequence sets in the Kingak Shale in the National Petroleum Reserve in Alaska

4. Map of the National Petroleum Reserve in Alaska (NPRA) showing thickness of Kingak Shale sequence set K1 and inferred clinoform dip directions ...........................

5. Wireline-log response in the K1 sequence set. 6

6. Part of a wireline log illustrating overlay of sonic and resistivity logs to define $\Delta \log R$ separation in an unidentified organic-matter-rich interval

7. Chart relating $\Delta \log R$, total organic carbon, and thermal maturity expressed as level of organic metamorphism..

8. Cross plot of log resistivity versus sonic travel time within the K2 sequence set of the Kingak Shale in the Ikpikpuk No. 1 well

9. Map of $\Delta D T_{\bar{x}}$ in the lower Kingak Shale for that part of the Alaska North Slope where requisite wireline-log data are available

10. Map of $\Delta D T_{z}$ in the lower Kingak Shale for that part of the Alaska North Slope where requisite wireline-log data are available

11. Gamma-ray log in American Petroleum Institute units, DT log in microseconds per foot, and total organic carbon content in weight percent of the Kingak Shale K1 and K2 sequence sets in the North Inigok well

12. Well logs from cross section $A-A$ 'illustrating regional change in $\triangle D T$ related to location in Kingak Shale K1-K3 sequence sets 


\section{Conversion Factors}

\begin{tabular}{|c|c|c|}
\hline Multiply & By & To obtain \\
\hline \multicolumn{3}{|c|}{ Length } \\
\hline foot (ft) & 0.3048 & meter $(\mathrm{m})$ \\
\hline mile (mi) & 1.609 & kilometer (km) \\
\hline
\end{tabular}

\section{Datum}

Horizontal coordinate information is referenced to the North American Datum of 1927 (NAD 27).

\section{Abbreviations}

$\begin{array}{ll}\text { API } & \text { American Petroleum Institute } \\ \Delta l o g R & \text { delta-log resistivity } \\ D T & \text { sonic travel time } \\ \text { GR } & \text { gamma-ray } \\ \text { HGR } & \text { high-gamma-ray } \\ \text { LAS } & \text { Log ASCII Standard } \\ \text { LCU } & \text { Lower Cretaceous unconformity } \\ \text { Hsec/ft } & \text { microseconds per foot } \\ \text { NPRA } & \text { National Petroleum Reserve in Alaska } \\ \text { ohm-m } & \text { ohm-meters } \\ \text { RILD } & \text { resistivity } \\ \text { RMA } & \text { reduced major axis } \\ \text { TOC } & \text { total organic carbon } \\ \text { USGS } & \text { U.S. Geological Survey }\end{array}$





\title{
Modified Method for Estimating Petroleum Source-Rock Potential Using Wireline Logs, With Application to the Kingak Shale, Alaska North Slope
}

\author{
By William A. Rouse and David W. Houseknecht
}

\begin{abstract}
In 2012, the U.S. Geological Survey completed an assessment of undiscovered, technically recoverable oil and gas resources in three source rocks of the Alaska North Slope, including the lower part of the Jurassic to Lower Cretaceous Kingak Shale. In order to identify organic shale potential in the absence of a robust geochemical dataset from the lower Kingak Shale, we introduce two quantitative parameters, $\Delta D T_{\bar{x}}$ and $\Delta D T_{z}$, estimated from wireline logs from exploration wells and based in part on the commonly used delta-log resistivity $(\Delta \log R)$ technique. Calculation of $\Delta D T_{\bar{x}}$ and $\Delta D T_{z}$ is intended to produce objective parameters that may be proportional to the quality and volume, respectively, of potential source rocks penetrated by a well and that can be used as mapping parameters to convey the spatial distribution of source-rock potential. Both the $\Delta D T_{\bar{x}}$ and $\Delta D T_{z}$ mapping parameters show increased source-rock potential from north to south across the North Slope, with the largest values at the toe of clinoforms in the lower Kingak Shale. Because thermal maturity is not considered in the calculation of $\Delta D T_{\bar{x}}$ or $\Delta D T_{z}$, total organic carbon values for individual wells cannot be calculated on the basis of $\Delta D T_{\bar{x}}$ or $\Delta D T_{z}$ alone. Therefore, the $\Delta D T_{\bar{x}}$ and $\Delta D T_{z}$ mapping parameters should be viewed as first-step reconnaissance tools for identifying source-rock potential.
\end{abstract}

\section{Introduction}

In 2012, the U.S. Geological Survey (USGS) completed an assessment of undiscovered, technically recoverable oil and gas resources in three source-rock systems (fig. 1) of the Alaska North Slope: (1) the Triassic Shublik Formation; (2) the lower part of the Jurassic to Lower Cretaceous Kingak Shale; and (3) the Cretaceous pebble shale unit, Hue Shale, and parts of the Paleogene Canning Formation, collectively called the Brookian shale (Houseknecht, Rouse, Garrity, and others, 2012). Maps of inferred source-rock richness were constructed using three parameters because of differences in lithology and wireline-log response among the source rocks. The map used for the Kingak Shale is highly generalized (fig. 2) because no quantitative mapping parameter had been defined. The study summarized in this report was initiated to evaluate the efficacy of the delta-log resistivity $(\Delta \log R)$ technique (Passey and others, 1990) for estimating an objective and quantitative parameter for evaluating source-rock potential from wireline-log data. This parameter may be useful as an evaluation tool for individual wells and, when calculated for multiple wells, as a mapping parameter. However, due to software limitations for digital calculation of $\Delta \log R$ and the absence of a robust geochemical dataset for calibration of $\Delta \log R$, we sought to develop a modified version of $\Delta \log R$ that yields two parameters that may serve as proxies of source-rock quality and volume. This report documents the digital workflow developed for calculating a modified version of $\Delta \log R$ and presents the results of applying the technique to evaluate source-rock potential of the lower Kingak Shale.

\section{Geologic Background}

The Jurassic to Lower Cretaceous Kingak Shale contains both marine and terrigenous organic matter deposited in a marine siliciclastic setting influenced by pulses of syndepositional uplift of the Beaufort rift shoulder (also known as the Barrow arch; see figs. 3 and 4) during opening of the Canada Basin (Magoon and Claypool, 1984; Hubbard and others, 1987; Bird and Houseknecht, 2011). Houseknecht and Bird (2004) identified four depositional sequence sets in the Kingak Shale (fig. 3, K1-K4) that define a northern-sourced southward-offlapping succession of Beaufortian strata in the National Petroleum Reserve in Alaska (NPRA), and these sequence sets subsequently have been mapped eastward beyond the NPRA on the basis of seismic and well data.

The basal $\mathrm{K} 1$ sequence set is 1,000 to more than 1,250 feet (ft) (300 to 380 meters [m]) thick across a broad area in the north-central NPRA that extends to the south as a lobe in the central NPRA (fig. 4). North of the zone of 


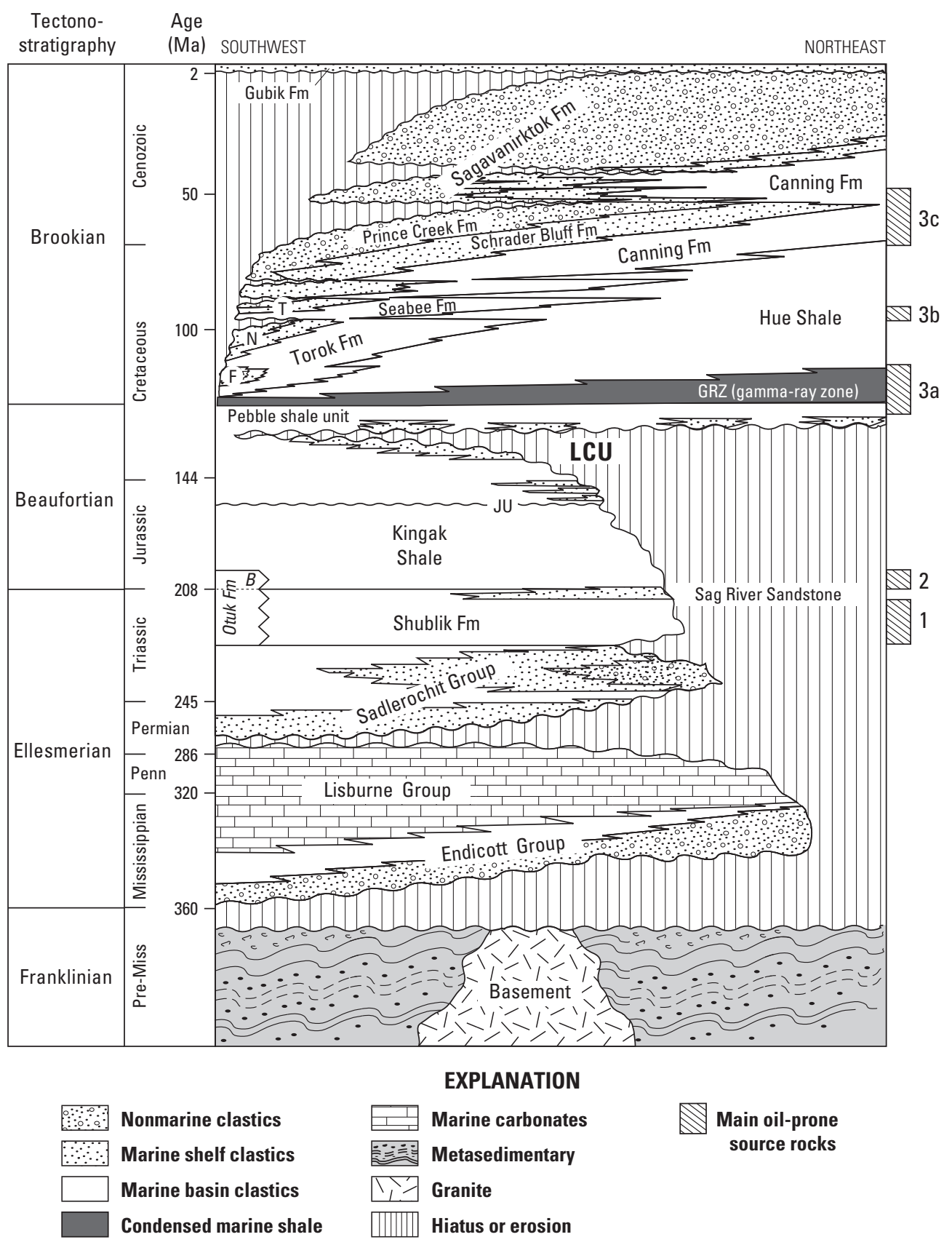

Figure 1. Diagram showing generalized chronostratigraphy for the Alaska North Slope (from Houseknecht, Bird, and Garrity, 2012). Oil-prone source-rock systems discussed in text are indicated at right: 1, Triassic source-rock system, composed of the Shublik Formation and the Triassic part of the Otuk Formation; 2, Jurassic source-rock system, composed of the lower part of the Kingak Shale and the Blankenship Member (B) of the Otuk Formation; and 3, Cretaceous to Cenozoic source-rock system, composed of (a) the Lower Cretaceous pebble shale unit and gamma-ray zone (GRZ), (b) Upper Cretaceous organic-matter-rich tongues of the Hue Shale, and (c) lower Paleogene organic-matter-rich tongues of the Canning Formation. Italicized labels (Otuk Formation and B) indicate units that crop out in the Brooks Range frontal thrust belt and that represent southern distal facies equivalents of formations present beneath the Alaska North Slope. Arctic Alaska stratigraphy modified from Lerand (1973), Bird (1985, 2001), Hubbard and others (1987), and Mull and others (2003); ages from Gradstein and others (2004) Abbreviations used: B, Blankenship Member of the Otuk Formation; F, Fortress Mountain Formation; Fm., Formation; GRZ, gamma-ray zone; JU, Jurassic unconformity; LCU, Lower Cretaceous unconformity; Ma, mega-annum, or million years ago; N, Nanushuk Formation; PENN, Pennsylvanian; Perm, Permian; Pre-Miss, pre-Mississippian; T, Tuluvak Formation. 


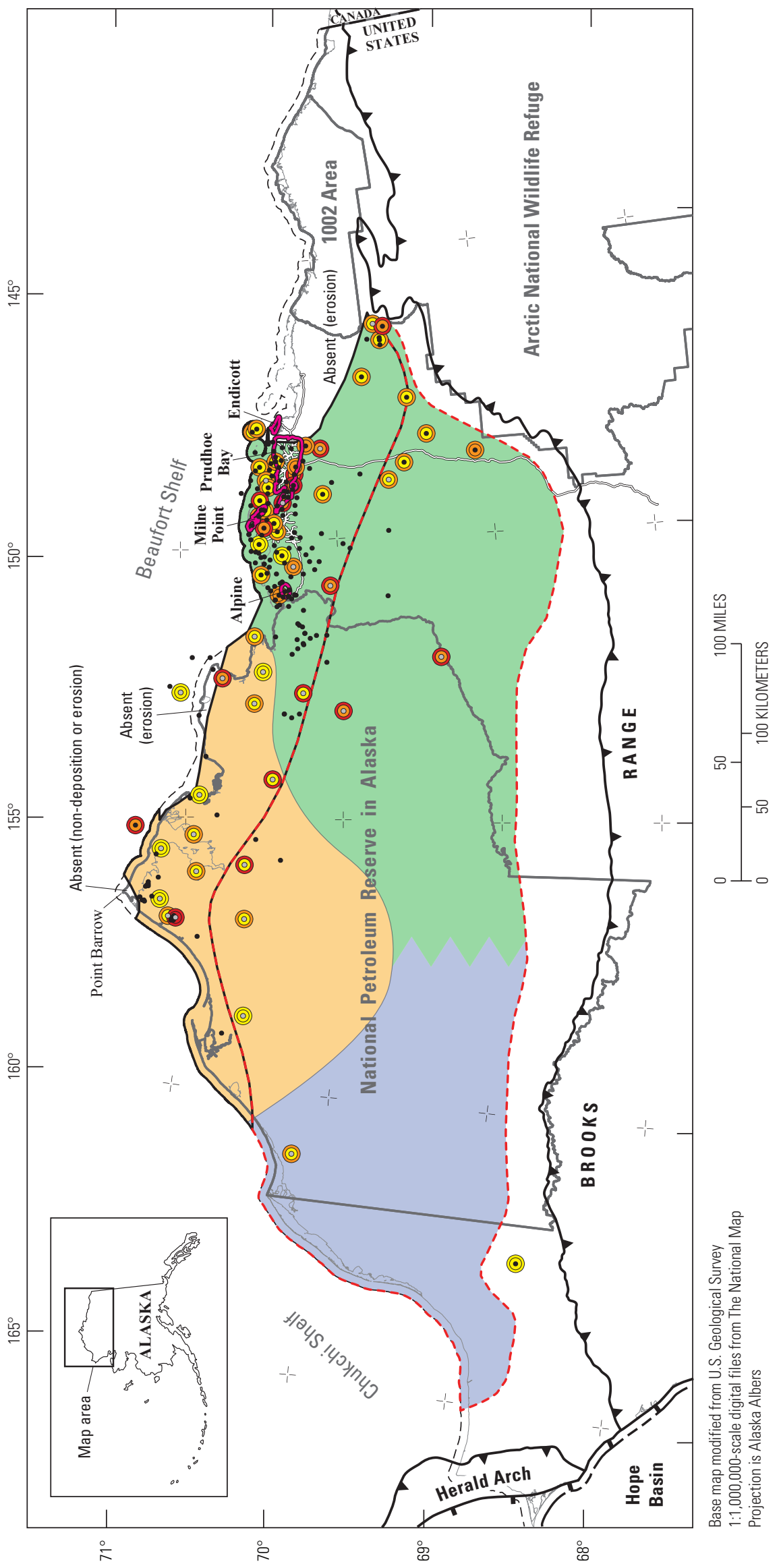

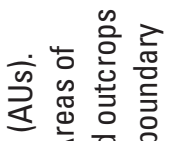

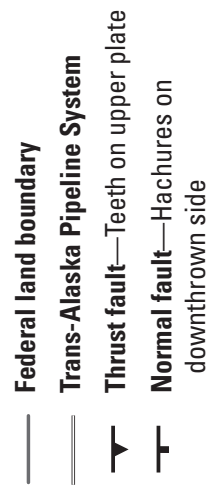

参造它

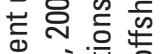

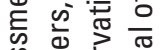

这吉这

둥 응

为市.

का कू

๘

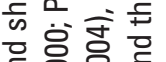

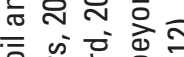

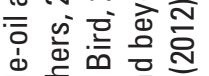

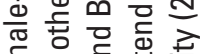

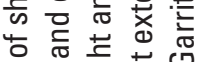

든 홍

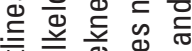

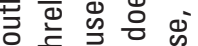

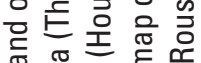

늉 눙

क

툰

荡흥 흔휴

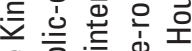

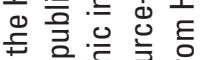

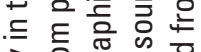

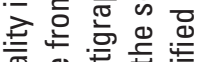

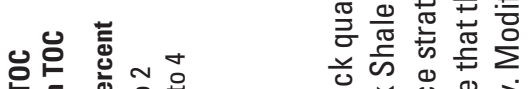

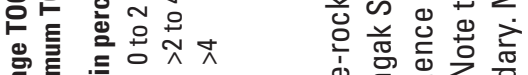

需至 000 d

总离它

())

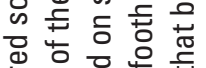

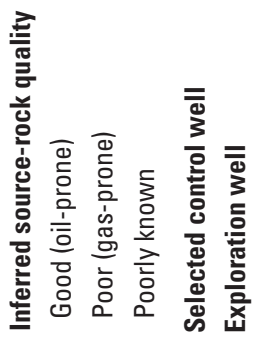

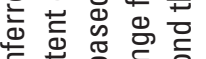

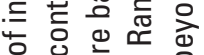

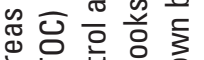

능

言

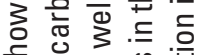

की 0 范

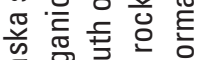

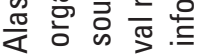

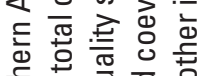

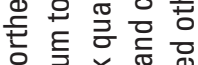

흘 들 원

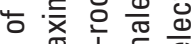

元焉过 的

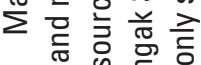

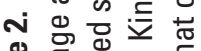

놓 

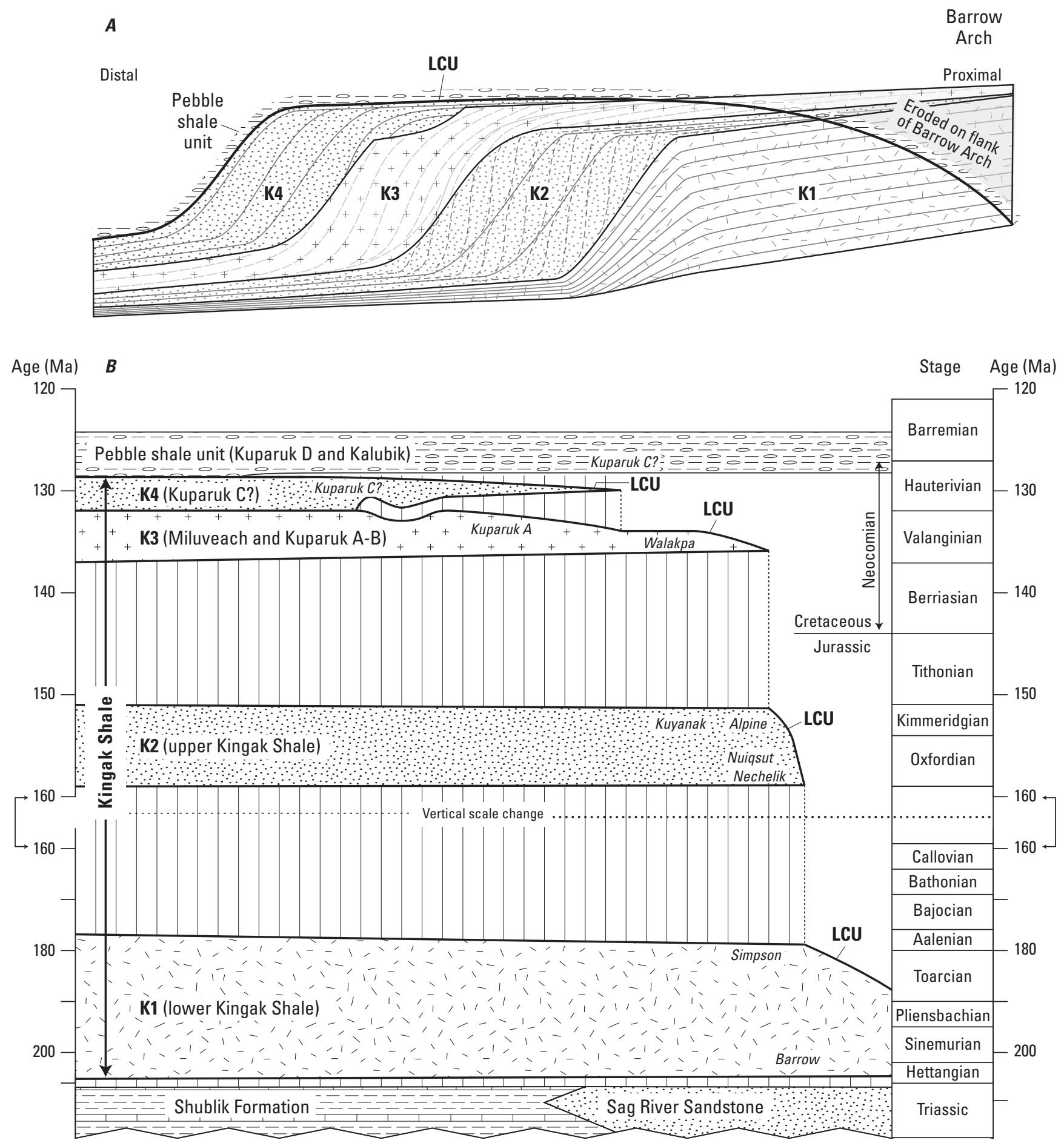

NOT TO SCALE

Figure 3. Schematic summary of inferred depositional sequence sets in the Kingak Shale in the National Petroleum Reserve in Alaska (modified from Houseknecht and Bird, 2004). A, Cross section from south (distal) to north (proximal) showing lithostratigraphic relations among four depositional sequence sets (K1-K4) and general aspects of internal stratal geometry. Note that the Lower Cretaceous unconformity (LCU) bevels Kingak Shale strata northward to extinction on the Barrow arch. $B$, Diagram showing chronostratigraphy of sequence sets in the Kingak Shale. Shown in parentheses are stratigraphic names widely applied to approximate age-equivalent strata of the four sequence sets. Names in italics show approximate positions of sandstone reservoirs and potential reservoirs. Vertical lines denote time gaps between sets. Note scale change near center of diagram. Geologic timescale from Gradstein and Ogg (1996). Abbreviation used: Ma, mega-annum, or million years ago. 


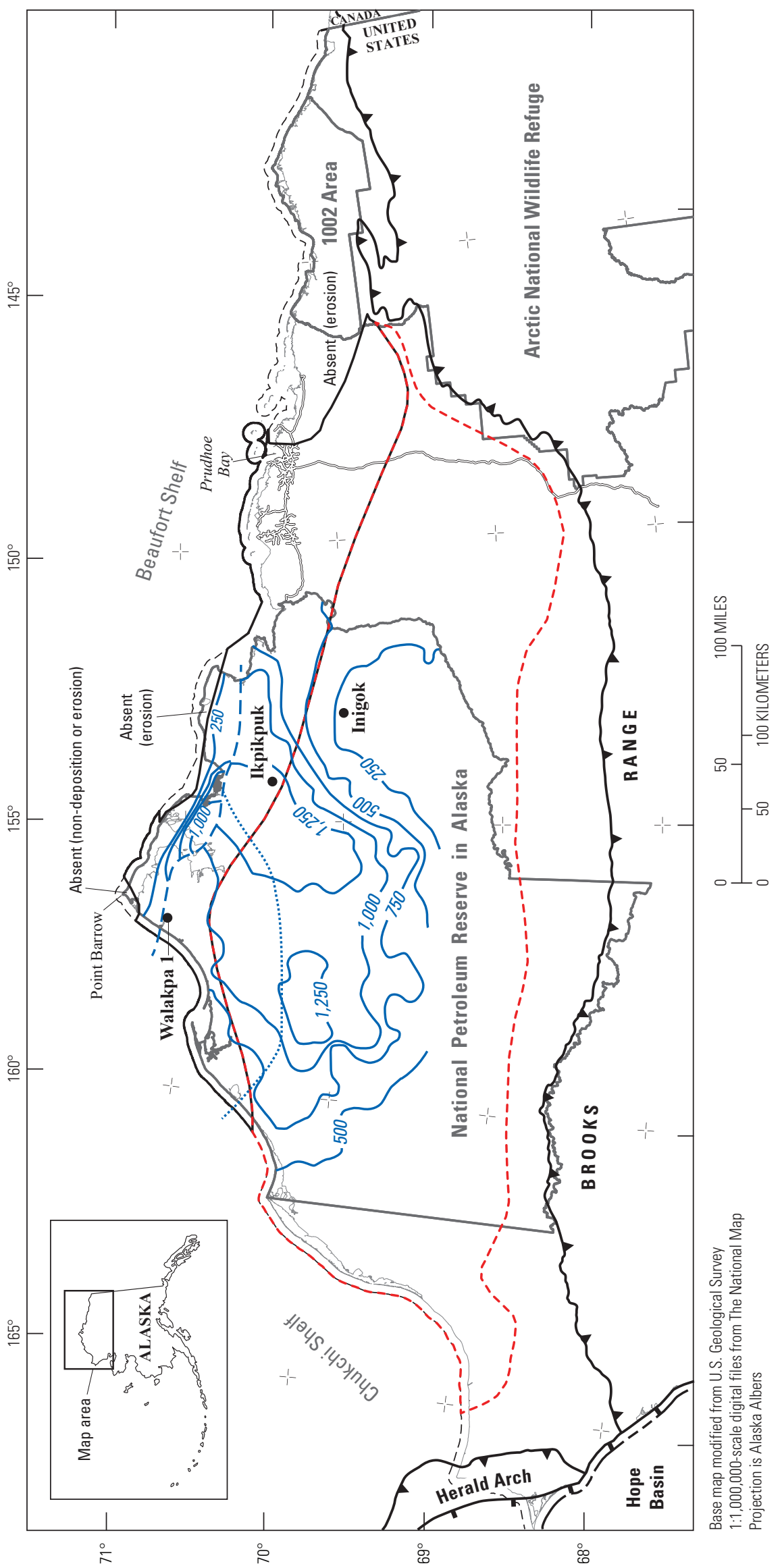

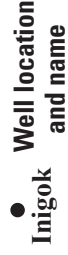

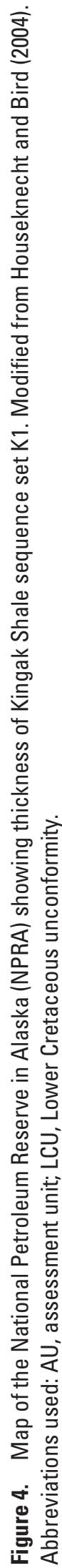


maximum thickness in the central NPRA, the K1 sequence set thins gradually where seismic data show an erosional contact between the K1 and K2 sequence sets. Farther north, the $\mathrm{K} 1$ sequence set abruptly thins to a zero edge along the trend of the Barrow arch, where it is beveled beneath the Lower Cretaceous unconformity. South of the zone of maximum thickness, the $\mathrm{K} 1$ sequence set abruptly thins in a radial pattern to less than $500 \mathrm{ft}(150 \mathrm{~m})$ in the western NPRA and to less than $250 \mathrm{ft}(76 \mathrm{~m})$ in the southeastern NPRA.

Wireline-log responses within the $\mathrm{K} 1$ sequence set in the northern NPRA commonly exhibit thin (<200 ft [61 m]) coarsening-upward trends consisting of mudstone grading upward to siltstone (for example, fig. 5, Walakpa 1 well, 2,980- to 2,800-ft [908- to 853-m] depth) or mudstone grading upward to sandstone (for example, fig. 5, Walakpa 1 well, 3,200- to 3,050-ft [975- to 930-m] depth). In contrast, fining-upward transitions commonly are abrupt between sandstone and siltstone (for example, fig. 5, Walakpa 1 well, $\sim 3,050-\mathrm{ft}$ [930-m] depth) or between siltstone and mudstone (for example, fig. 5, Walakpa 1 well, 2,990-ft [911-m] depth), with an additional few thin fining-upward successions also present (for example, fig. 5, Walakpa 1 well, 2,800- to 2,770-ft [853- to 844-m] depth; Houseknecht and Bird, 2004).

Within the zone of maximum thickness in the central NPRA, wireline-log responses within the K1 sequence set display subtle coarsening-upward successions capped by siltstone abruptly overlain by shale, as well as repetitive intervals of silty mudstone locally punctuated by shale (fig. 5, Ikpikpuk well). The wireline-log response in the most distal well penetrations of the K1 sequence set in the eastern NPRA displays an off-the-scale gamma-ray response in a thin interval of silty mudstone near or beyond the toe of K1 clinoforms (fig. 5, Inigok well).

The distal increase in gamma-ray response within the $\mathrm{K} 1$ sequence set was interpreted as increased organic matter content and coalescence of time lines (that is, it is a condensed section) in a distal direction by Houseknecht and Bird (2004). Biostratigraphic data from NPRA wells indicate that the K1 sequence set is Early to Middle Jurassic, equivalent to the lower Kingak Shale in the central North Slope (Carman and Hardwick, 1983; Masterson and Paris, 1987). Conventional oil accumulations at the Alpine, Endicott, Milne Point, and Prudhoe Bay fields were sourced entirely or partly from the lower Kingak Shale (fig. 2; Seifert and others, 1980; Claypool and Magoon, 1985; Premuzic and others, 1986; Sedivy and others, 1987; Masterson, 2001; Magoon and others, 2003; Peters and others, 2006). The potential for self-sourced, continuous accumulations of recoverable oil and gas in lower Kingak Shale source rocks is assumed to exist (Houseknecht, Rouse, and Garrity, 2012) but has not been confirmed by well completions.

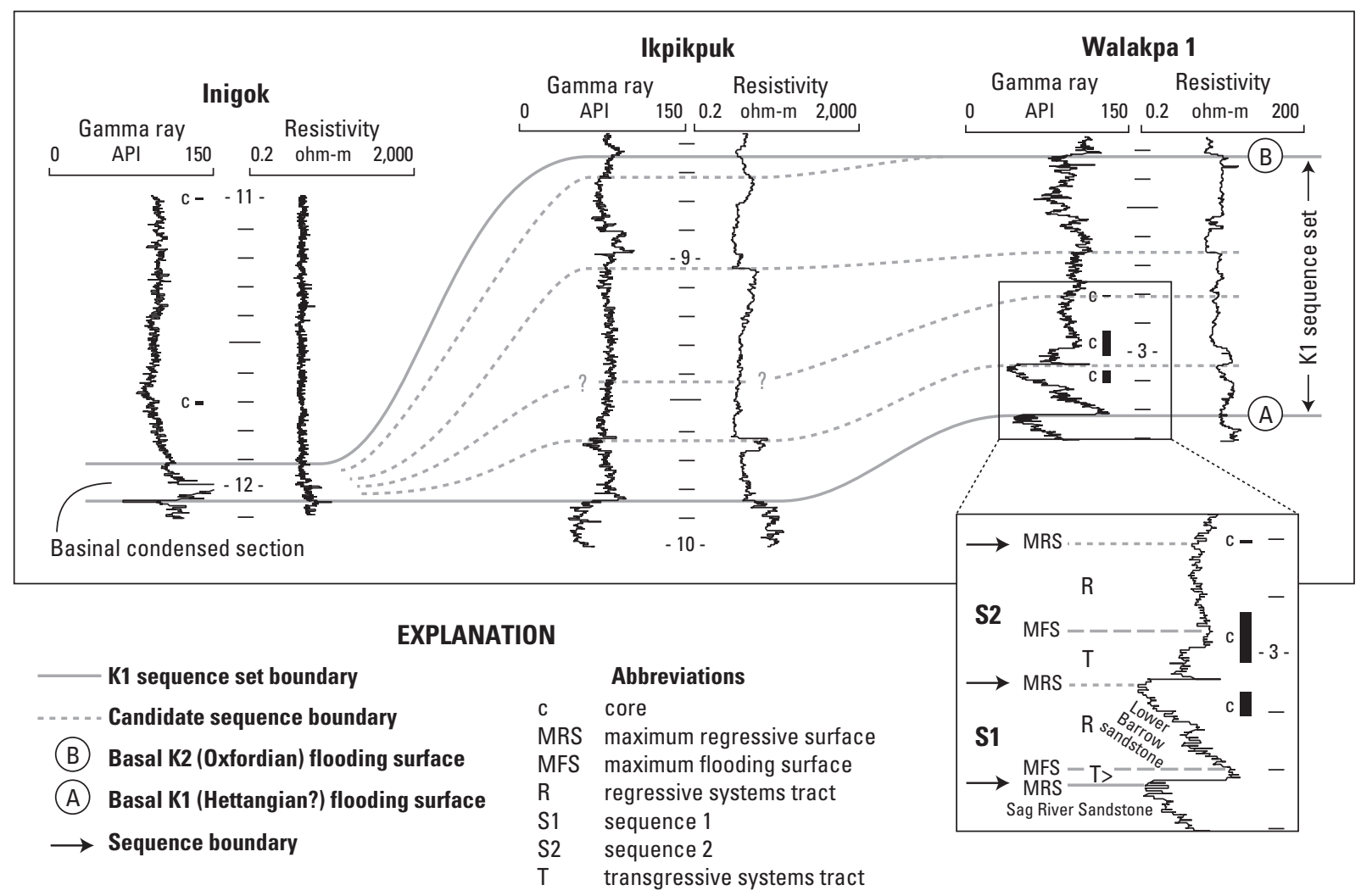

Figure 5. Wireline-log response in the $\mathrm{K} 1$ sequence set. Well locations are shown in figure 4. Wireline-log measured depth ticks below kelly bushing are at 100-foot ( $\mathrm{ft}$ ) (30-meter) intervals, and numbers are $\times 1,000 \mathrm{ft}$. Modified from Houseknecht and Bird (2004). Abbreviations used: ohm-m, ohm-meter; API, American Petroleum Institute. 


\section{Source-Rock Characterization With Wireline Logs}

Petroleum source rocks typically are shale or limestone containing more than 1 or 2 weight percent of organic matter (Tissot and Welte, 1984). Direct geochemical measurements on source rocks are generally sparse, resulting in the increased use of common wireline logs from exploration and development wells for identifying source-rock intervals and estimating organic matter content. Recognition of organic-matter-rich strata from wireline logs is based on the unique physical properties of organic matter as compared to minerals in the host rock. These properties include higher radioactivity (Beers, 1945; Schmoker, 1981), lower density (Schmoker, 1979), higher resistivity (Nixon, 1973; Meissner, 1978; Schmoker and Hester, 1989), and slower sonic velocity or higher sonic travel time (Dellenbach and others, 1983).

Previous assessments of technically recoverable shale-gas resources by the USGS have used a high-gamma-ray (HGR; gamma-ray greater than 150 American Petroleum Institute [API] units) mapping parameter as a possible indication of source-rock richness (Houseknecht and others, 2014). Whereas gamma-ray response increases distally within the lower Kingak Shale, gamma-ray values rarely exceed 150 API except for a thin interval near the base of the formation in distal parts of the depositional system, precluding the use of the HGR mapping parameter in identifying source-rock potential and necessitating an alternative methodology.

Meyer and Nederlof (1984) developed a method involving a combination of density, resistivity, and sonic logs that discriminates between source rocks and non-source rocks without attempting to quantify the organic-matter richness from the combination of logs. Their technique uses cross plots of density versus resistivity and of sonic travel time versus resistivity; strata with relatively high resistivity and either relatively high sonic travel time or low bulk density represent a potential source rock. A regression line is fit through the cross-plot data, the equation of which becomes the discriminant function for separating potential source rock from non-source rock.

Passey and others (1990), using a principle similar to that of Meyer and Nederlof (1984), developed a method called delta-log resistivity $(\Delta \log R)$ that identifies potential source rocks by overlaying the sonic curve and the resistivity curve in a baseline interval consisting of clay-rich rocks (mudstone or shale) that are not of source-rock quality (fig. 6). Potential source rocks in other depth intervals of the well are identified by a separation of the two curves through the parameter quantified in the following equation:

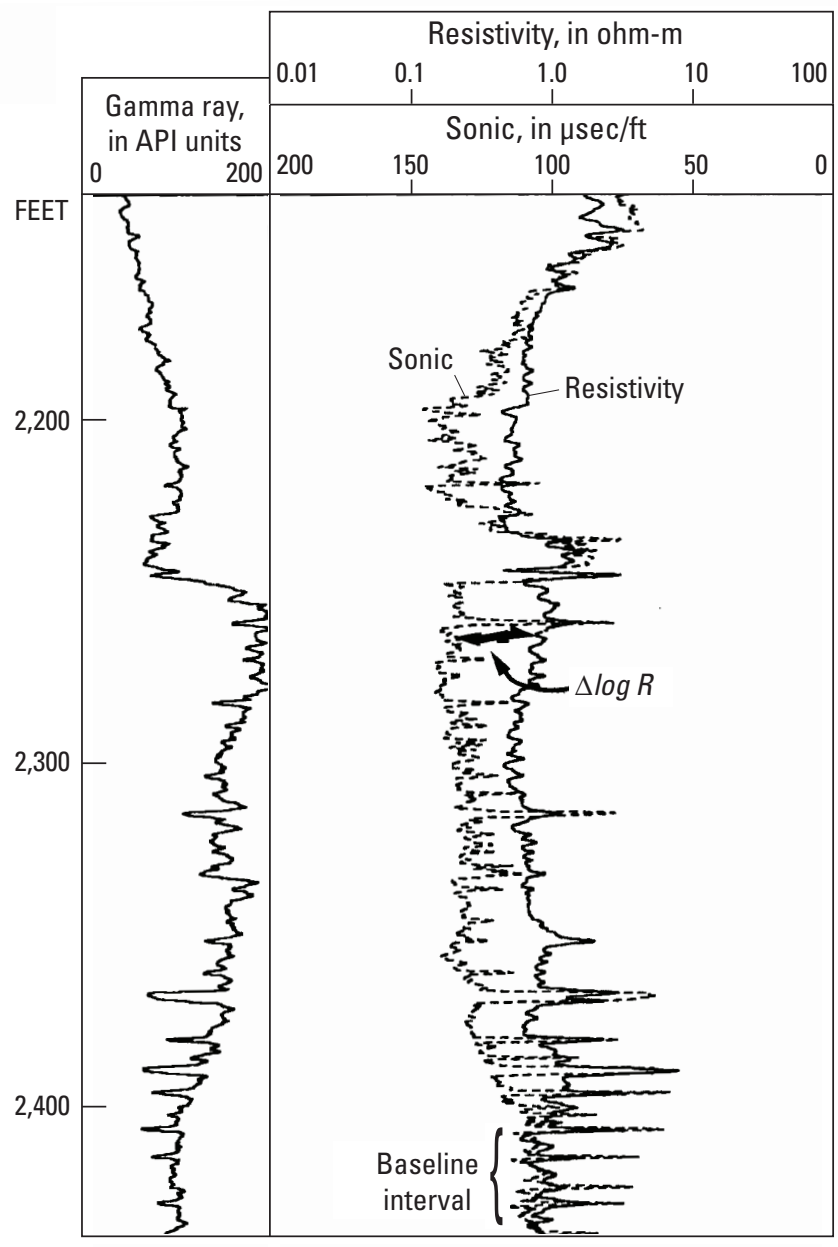

Figure 6. Part of a wireline log illustrating overlay of sonic and resistivity logs to define $\Delta \log R$ separation in an unidentified organic-matter-rich interval. Scaling of the sonic and resistivity curves is adjusted so that $50 \mu \mathrm{sec} / \mathrm{ft}$ on the sonic log corresponds to one decade of resistivity. The values in the center of the sonic and resistivity log track correspond to the $R_{\text {baseline }}$ and $\Delta t_{\text {baseline }}$ values (for this example, $R_{\text {baseline }}=1 \mathrm{ohm}-\mathrm{m}$, and $\Delta t_{\text {baseline }}=100 \mu \mathrm{sec} / \mathrm{ft}$ ). Wireline-log measured depth ticks below kelly bushing are at 100-foot (ft) (30-meter) intervals. Figure from Passey and others (1990). Abbreviations used: ohm-m, ohm-meter; $\mu \mathrm{sec} / \mathrm{ft}$, microsecond per foot; m, meter; API, American Petroleum Institute. 


$$
\Delta \log R=\log _{10}\left(\frac{R}{R_{\text {baseline }}}\right)+0.02 \times\left(\Delta t-\Delta t_{\text {baseline }}\right)
$$

where

$$
\begin{aligned}
& \Delta \log R \quad \text { is the curve separation measured in } \\
& \text { logarithmic resistivity cycles; } \\
& R \quad \text { is the resistivity measured in ohm-meters } \\
& \text { (ohm-m); } \\
& \Delta t \quad \text { is the measured sonic travel time in } \\
& \text { microseconds per foot }(\mu \mathrm{sec} / \mathrm{ft}) \text {; } \\
& R_{\text {baseline }} \quad \text { is the resistivity corresponding to the } \\
& \Delta t_{\text {baseline }} \text { value when the curves are } \\
& \text { overlain in non-source, clay-rich rocks; and } \\
& 0.02 \text { is based on the ratio of }-50 \mu \mathrm{sec} / \mathrm{ft} \text { per } \\
& \text { resistivity cycle. }
\end{aligned}
$$

Passey and others (1990) found a linear correlation between $\Delta \log R$ separation and total organic carbon (TOC) content in multiple source rocks as a function of thermal maturity (fig. 7). The original calibration of the $\Delta \log R$ technique (Passey and others, 1990) was for source rocks in the oil window, as there was no calibration at that time to include rocks of higher thermal maturity (Passey and others, 2010). Sondergeld and others (2010) proposed using a correction multiplier to obtain $\log$-derived TOC using the $\Delta \log R$ technique for overmature shale-gas formations:

$$
\mathrm{TOC}=\Delta \log R \times 10^{(2.297-0.1688 \times L O M)} \times C
$$

where

$$
\begin{aligned}
& \text { TOC is the total organic carbon measured in } \\
& \text { weight percent, } \\
& \text { is the level of organic metamorphism } \\
& \text { (Hood and others, 1975), and } \\
& C \quad \text { is a correction factor. }
\end{aligned}
$$

\section{Methodology}

The methodology used in this study for identifying organic shale potential is based on a combination of the cross-plot and $\Delta \log R$ methods (Meyer and Nederlof, 1984; Passey and others, 1990) and follows an example presented by Bowman (2010). Our digital workflow was developed and tested using IHS Kingdom ${ }^{\circledR}$ version 8.8 software. The following procedures were performed on a well-by-well basis.

To assure adequate non-source-rock strata with which to determine a baseline for sonic and resistivity data, we defined a target stratigraphic interval that includes both the K1 and the overlying K2 sequence sets (fig. 3) in the Kingak Shale, where the $\mathrm{K} 2$ sequence set is assumed to consist of predominately non-source-rock strata. The target stratigraphic interval was identified by examining wireline-log and seismic data across the North Slope. To constrain the analysis to clay-rich intervals within the $\mathrm{K} 2$ and $\mathrm{K} 1$ sequence sets, shale volume was calculated for each well using the following equation:

$$
V_{\text {sh }}=\left(\frac{G R_{\text {log }}-G R_{\text {clean }}}{G R_{\text {shale }}-G R_{\text {clean }}}\right)
$$

where

$$
\begin{gathered}
V_{\text {sh }} \quad \text { is the shale volume (decimal percent), } \\
G R_{\text {log }} \quad \text { is the API value from the gamma-ray } \\
\quad \log \text { curve, } \\
G R_{\text {clean }} \quad \begin{array}{l}
\text { is the API value of a "clean" sand, and } \\
G R_{\text {shale }}
\end{array} \quad \text { is the API value of a shale. }
\end{gathered}
$$

$G R_{\text {clean }}$ and $G R_{\text {shale }}$ values were computed for each well using the IHS Kingdom ${ }^{\circledR}$ version 8.8 software Petrophysics module. Only strata consisting of at least 60 percent shale

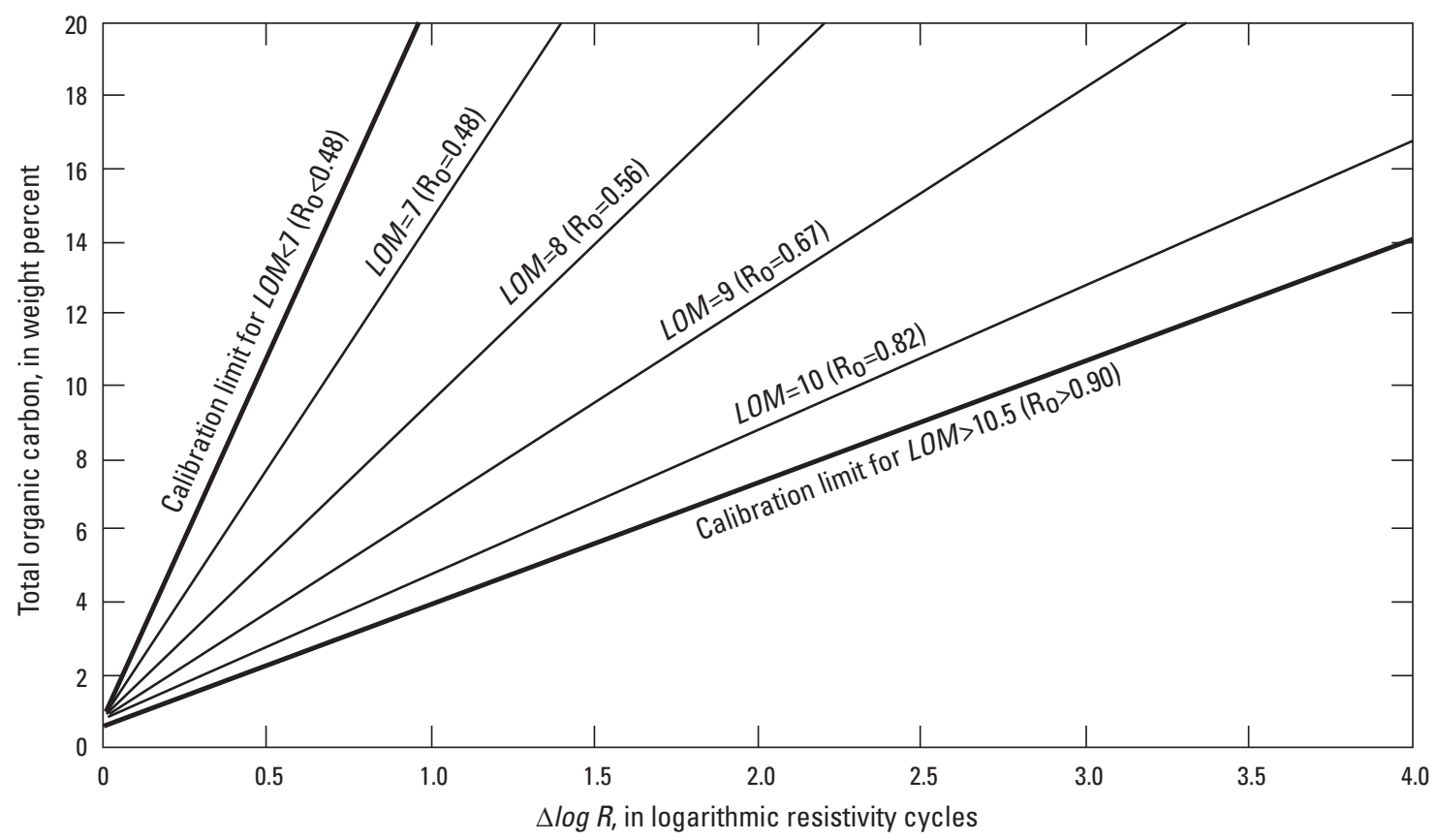

Figure 7. Chart relating $\Delta \log R$, total organic carbon, and thermal maturity expressed as level of organic metamorphism (LOM) (Hood and others, 1975). Abbreviations used: $\mathrm{R}_{0}$, vitrinite reflectance. 
by volume $\left(V_{s h} \geq 0.6\right)$ were considered suitable as a baseline (Tom Wild, President and Owner, Tom Wild Petrophysical Services LLC, written commun., February 27, 2013). Fiftyfour wells were identified with suitable shale intervals and complete digital gamma-ray (GR), resistivity (RILD), and sonic travel time $(D T)$ wireline-log data that extend through the $\mathrm{K} 2$ and $\mathrm{K} 1$ sequence sets.

The inability to display linear and logarithmic data on the same log track in IHS Kingdom ${ }^{\circledR}$ version 8.8 software precluded digital curve manipulation of the $\Delta \log R$ methodology (Passey and others, 1990) to determine baseline values for non-source-rock shale intervals. As an alternative, cross plots of sonic travel time versus resistivity were constructed for each well (Bowman, 2010). Cross-plot data were constrained to the assumed non-source-rock K2 sequence set and a reduced major axis (RMA) regression line was fit through the data, thus automating the determination of Bowman's (2010) low-resistivity shale line. The resultant correlation equation then was used to calculate a pseudosonic $\log D T_{\log R}$ which transformed resistivity data into sonic travel time units $(\mu \mathrm{sec} / \mathrm{ft})$, thereby enabling the direct comparison of sonic and resistivity log data within the same unit space and scaling the resistivity data to overlie the sonic data in the assumed non-source-rock interval (equation 4, fig. 8).

$$
D T_{\log R}=b-m \times \log R
$$

where

$$
\begin{aligned}
m & \text { is the slope and } \\
b & \text { is the y-intercept of a line. }
\end{aligned}
$$

In two cases where individual wells exhibited an inverse regression trend (positive $m$ value), values for $b$ and $m$ were substituted from the nearest well. The $D T_{\log R}$ curve calculation (equation 4) then was applied to both $\mathrm{K} 2$ and $\mathrm{K} 1$ sequence sets. Curve separation within the lower Kingak Shale $\mathrm{K} 1$ sequence set was calculated using the following equation:

$$
\Delta D T=D T-D T_{\log R}
$$

where $\Delta D T$ is the separation between $D T$ and $D T_{\text {logR }}$ curves (in units of $\mu \mathrm{sec} / \mathrm{ft}$ ), a transform functionally similar to $\Delta \log R$ of Passey and others (1990).

It should be noted that whereas $\triangle D T$ is functionally similar to $\Delta \log R$ of Passey and others (1990), the application of the RMA transform in the calculation of $D T_{\text {logR }}$ ultimately distorts the resistivity data. Thus, $\Delta D T$ values may not be equivalent to $\Delta \log R$ values in all cases.

We assumed the existence of a positive relationship between $\Delta \log R$ and TOC, as documented by Passey and others $(1990,2010)$ (fig. 7), to infer qualitatively the presence of potential source-rock intervals in the lower Kingak Shale K1 sequence set. Although this revised methodology addressed the presence of potential source rocks by the calculation of $\triangle D T$, our objectives also included the development of a parameter that may be proportional to the volume of potential source rocks in a well. We therefore introduced an additional

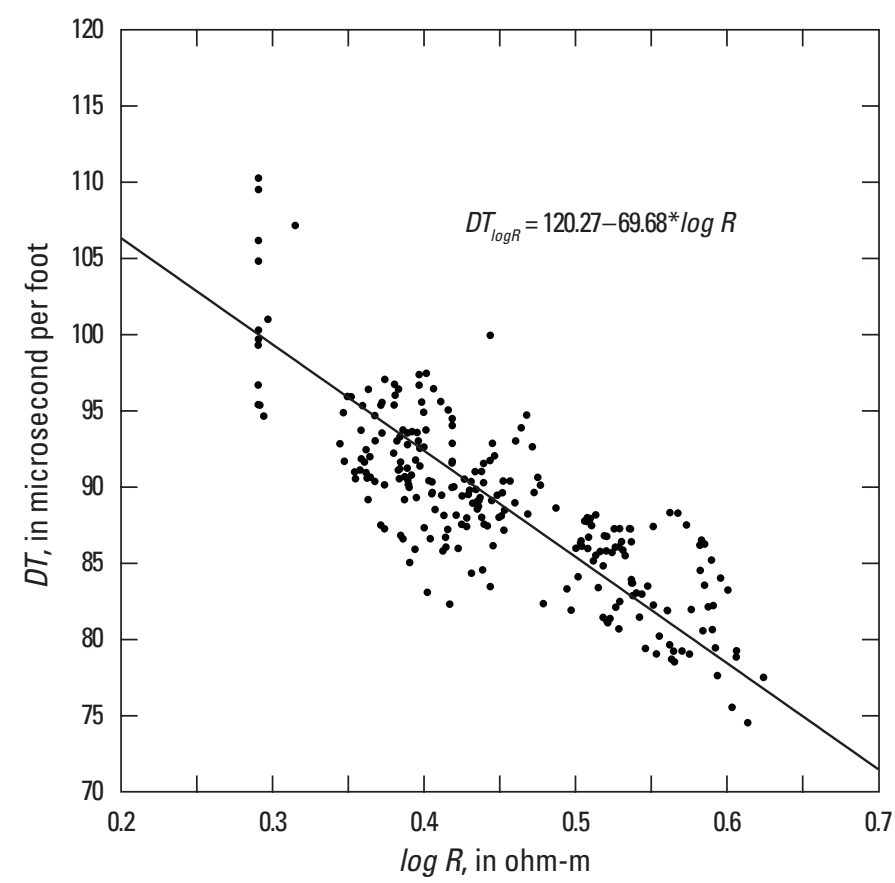

Figure 8. Cross plot of $\log$ resistivity $(\log R)$ versus sonic travel time $(D T)$ (both derived from wireline logs) within the K2 sequence set of the Kingak Shale in the Ikpikpuk No. 1 well (location shown in figures 9 and 10). The equation of the reduced major axis (RMA) regression line is used to transform resistivity-log data into sonic travel time units, enabling the direct comparison of sonic- and resistivity-log data within the same unit space. Abbreviations used: ohm-m, ohm-meter; $\mu \mathrm{sec} / \mathrm{ft}$, microsecond per foot.

parameter, $\Delta D T_{z}$, which incorporated both the magnitude and thickness of the $\triangle D T$ curve separation, defined as:

$$
\Delta D T_{z}=\Delta D T_{\bar{x}} \times h_{n e t}, \Delta D T>0
$$

where

$$
\begin{gathered}
\Delta D T_{\bar{x}} \quad \text { is the mean of positive } \Delta D T \text { values calculated } \\
\text { within the stratigraphic interval of interest } \\
\text { (K1 sequence set, in this example) and } \\
h_{n e t} \quad \text { is the net vertical interval in feet, over } \\
\text { which } \Delta D T \text { exceeds zero within the } \\
\text { subject interval. }
\end{gathered}
$$

$\Delta D T_{\bar{x}}$ may be used as a proxy of the overall source-rock quality in a stratigraphic interval of interest. $\Delta D T_{\bar{x}}$ and $\Delta D T_{z}$ were only calculated where $\Delta D T$ was greater than zero, as positive values represent higher resistivity and higher sonic travel times indicative of possible source rocks. Definition of $\Delta D T_{z}$ to include both the magnitude and thickness of positive $\triangle D T$ values was intended to produce an objective parameter that may be proportional to the volume of potential source rocks penetrated by each well. Following the calculation of $\Delta D T_{\bar{x}}$ and $\Delta D T_{z}$ for each well, the results for the lower Kingak Shale K1 sequence set were mapped (figs. 9, 10) using a gridding algorithm in IHS Kingdom ${ }^{\circledR}$ version 8.8 software. A digital workflow for calculation of $\Delta D T_{\bar{x}}$ and $\Delta D T_{z}$ using IHS Kingdom ${ }^{\circledR} 8.8$ software is presented in appendix 1 . 

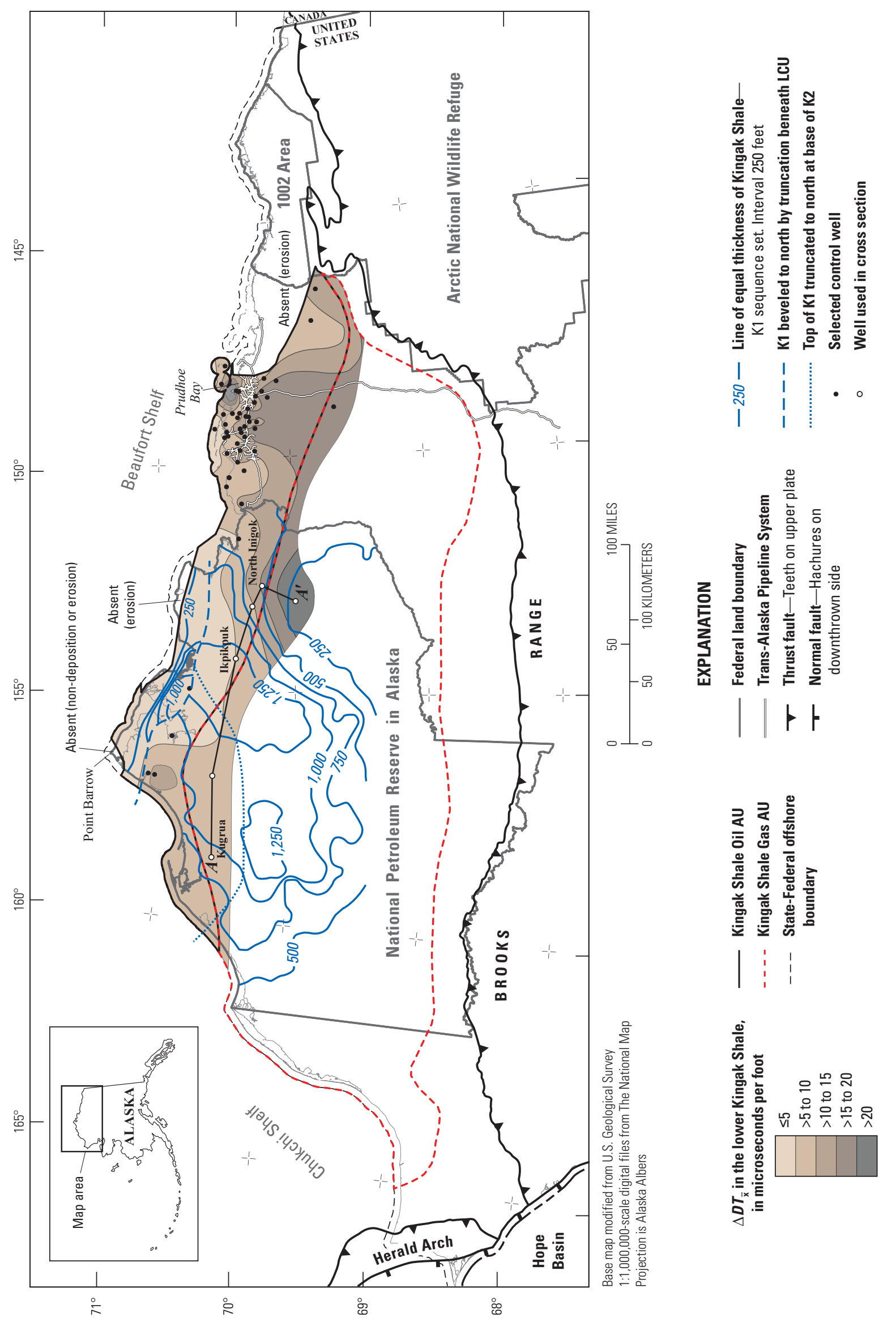

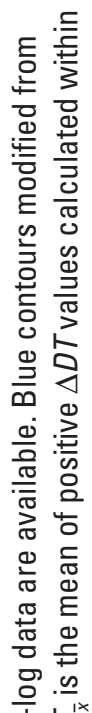

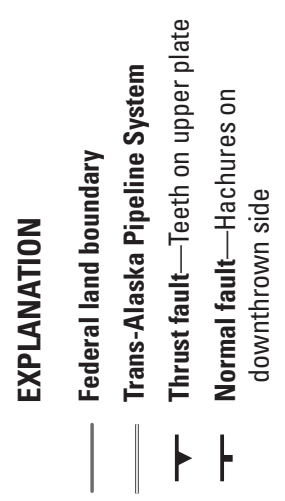

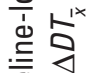

产

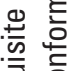

흥

递害

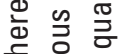

उ

业

은

言 离

은 宁尔

苋㻤

西要

过芒

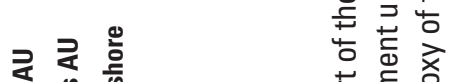

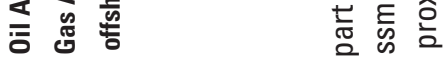

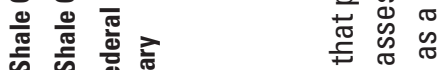

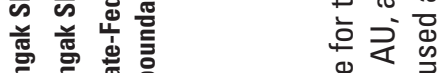

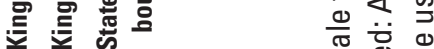

| $1 \begin{array}{r}1 \\ \vdots \\ 1\end{array}$

क⿺

离

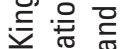

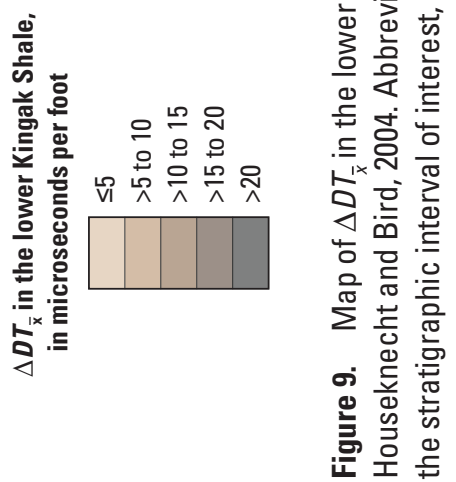



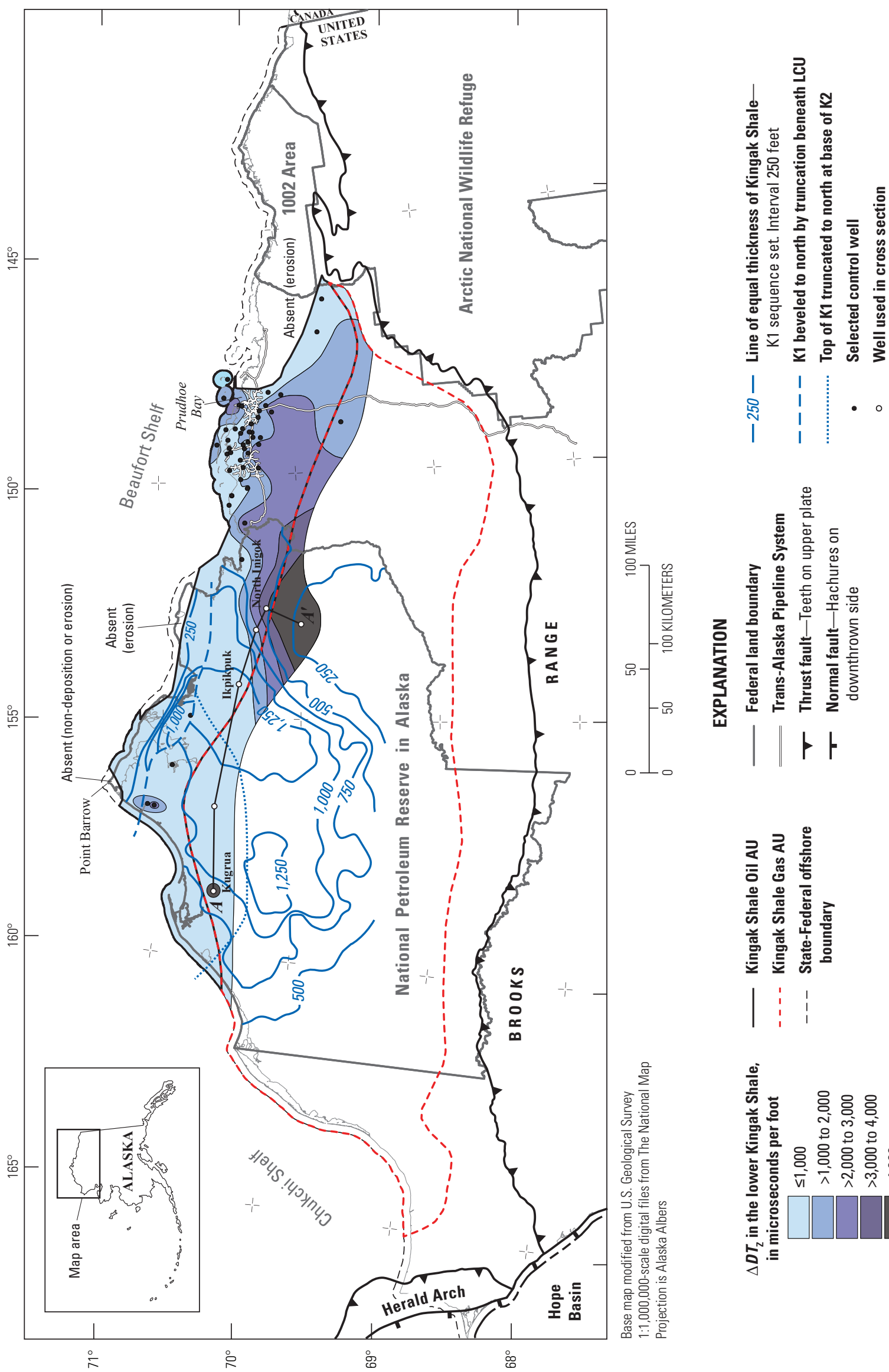

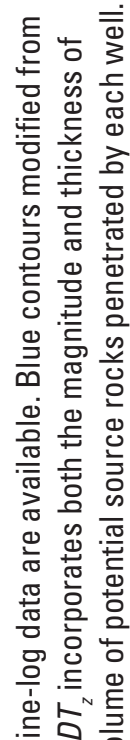

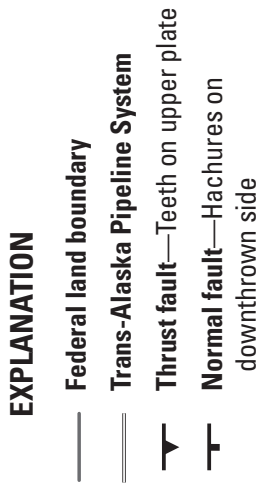

응

产声

농요

言珫

잉

혹응 을

응 융

क인 उ

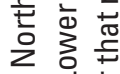

芩要

远它

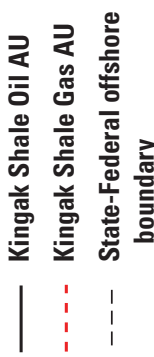

范

或

苋

蛋

웅웡

要亲 흥

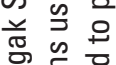

章高

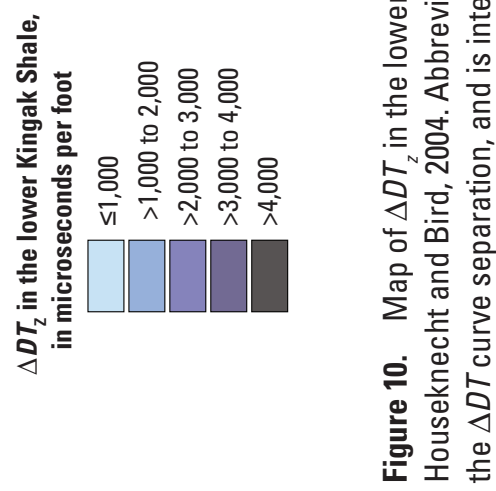




\section{Discussion}

The $\Delta D T_{\bar{x}}$ and $\Delta D T_{z}$ parameters were developed to serve as proxies for potential source-rock quality and volume, respectively, in the absence of geochemical and thermal maturity data necessary for the direct correlation of TOC $\log$ and geochemical data. Geochemical data from the lower Kingak Shale are sparse and largely derived from cuttings collected over intervals of 10 to $100 \mathrm{ft}$ (3 to $30 \mathrm{~m}$ ). Moreover, most of the available TOC data were concentrated in relatively proximal parts of the Kingak Shale depositional system that lack organic-matter-rich and oil-prone source rocks, making a direct comparison of TOC and $\triangle D T$ in potential source-rock intervals difficult. However, where TOC measurements were available in potential source-rock intervals, $\triangle D T$ and TOC values were positively correlated (for example, North Inigok; fig. 11).

Maps of $\Delta D T_{\bar{x}}$ and $\Delta D T_{z}$ in the $\mathrm{K} 1$ sequence set reveal an increase in potential source-rock quality and volume, respectively, from north to south. The potentially richest area in the eastern NPRA corresponds to a re-entrant in the K1 shelf margin, as defined by a K1 isopach map (figs. 9, 10). Within the NPRA, $\Delta D T_{\bar{x}}$ and $\Delta D T_{z}$ values are inversely related to the thickness of the $\mathrm{K} 1$ sequence set, with the greatest values where the $\mathrm{K} 1$ sequence set thins distally (fig. 12). These findings agree with Houseknecht and Bird's (2004) interpretation of a distal increase in organic matter content within the $\mathrm{K} 1$ sequence set in the NPRA. Outside of the NPRA, $\Delta D T_{\bar{x}}$ and $\triangle D T_{z}$ values gradually decrease eastward toward the Arctic National Wildlife Refuge (figs. 9, 10). An exception to this regional trend occurs in the Prudhoe Bay area, where a pod of large $\Delta D T_{\bar{x}}$ and $\Delta D T_{z}$ values highlight a potential rich source-rock area, although the controls are not understood (figs. 9, 10).

The large $\Delta D T_{z}$ value calculated for the Kugrua well (location shown in figure 10) is attributed to elevated methane concentrations within shale of the K2 interval (Hayba and others, 2002), skewing the shale baseline values meant to be derived in a non-source-rock interval. This results in an offset of the $D T$ and $D T_{\log R} \log$ curves within the $\mathrm{K} 1$ interval, where the curves otherwise would be superimposed. This small curve separation (as evident in figure 9), combined with the thickness of the K1 sequence set preserved in the proximal portion of the basin, result in a large $\Delta D T_{z}$ value that is unlikely to correspond to a large volume of potential source rock.

\section{Conclusions}

The methodology outlined in this report can be used in a completely digital workflow to evaluate the richness and volume of potential source rocks, both in individual wells and in a map area containing multiple wells, provided that a non-source-rock interval of mudstone or shale can be identified to establish a baseline for comparison. Use of $\Delta D T_{\bar{x}}$ and $\Delta D T_{z}$ parameters delineates regional source-rock potential in the lower Kingak Shale, and map results are consistent with known patterns of lithofacies and geochemistry. However, because thermal maturity was not considered in the calculation of these parameters in the Kingak Shale test case, TOC values cannot be estimated for individual wells or regionally. Therefore, the $\Delta D T_{\bar{x}}$ and $\Delta D T_{z}$ mapping parameters should be viewed as first-step reconnaissance tools for identifying possible source-rock potential.

\section{Acknowledgments}

We thank Tom Wild, President and Owner of Tom Wild Petrophysical Services LLC, for insightful discussion on geophysical-log interpretation. 


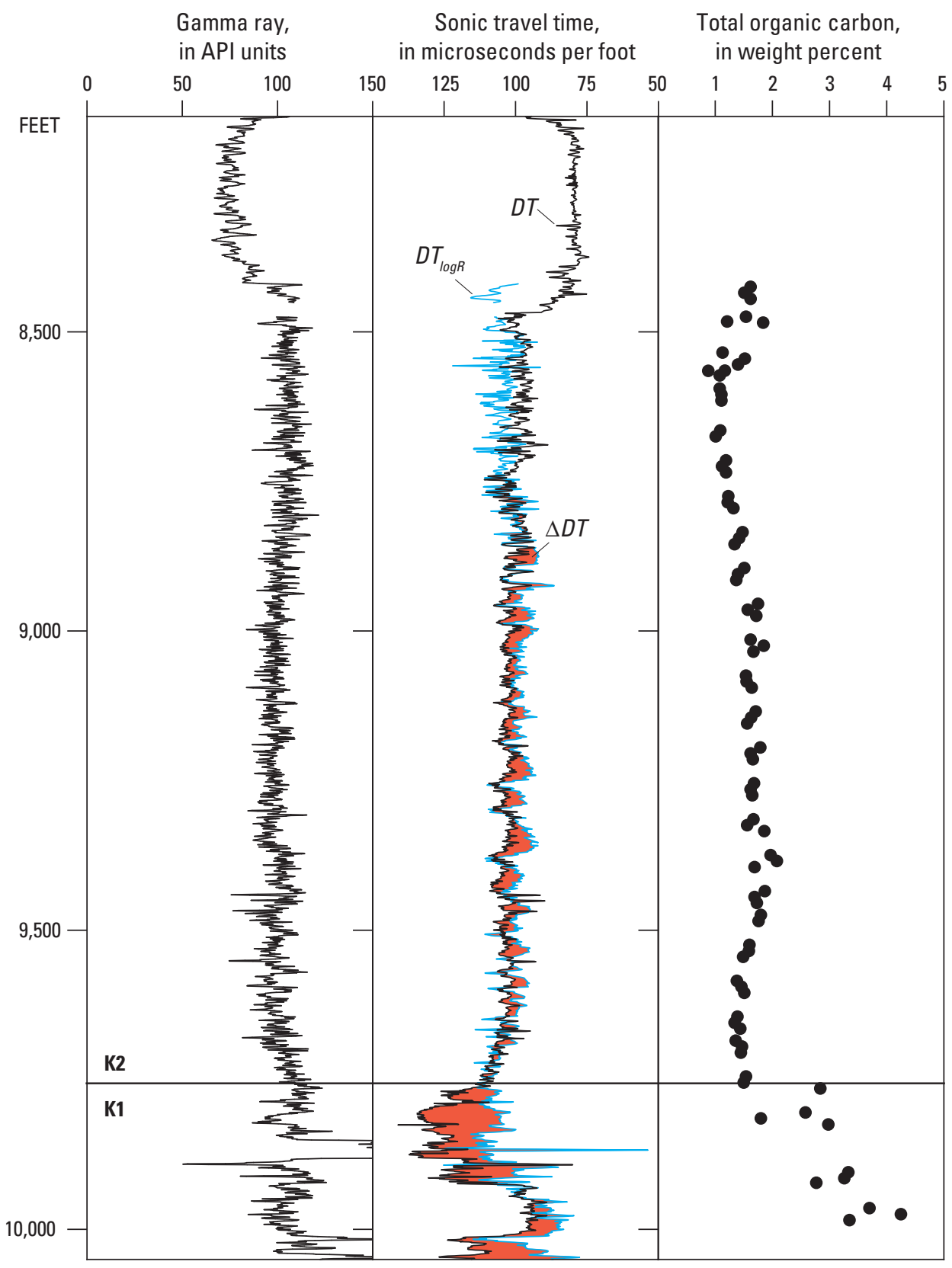

Figure 11. Gamma-ray log, sonic travel time, and total organic carbon content of the Kingak Shale K1 and K2 sequence sets in the North Inigok well (location shown in figures 9 and 10). Greater positive separation of the $D T$ and $D T_{\operatorname{logh}}$ curves $(\triangle D T$; highlighted in red) in the $\mathrm{K} 1$ sequence set correlates with high total organic carbon values. Depths are below kelly bushing. Abbreviations: API, American Petroleum Institute; DT, sonic travel time. 
$A$

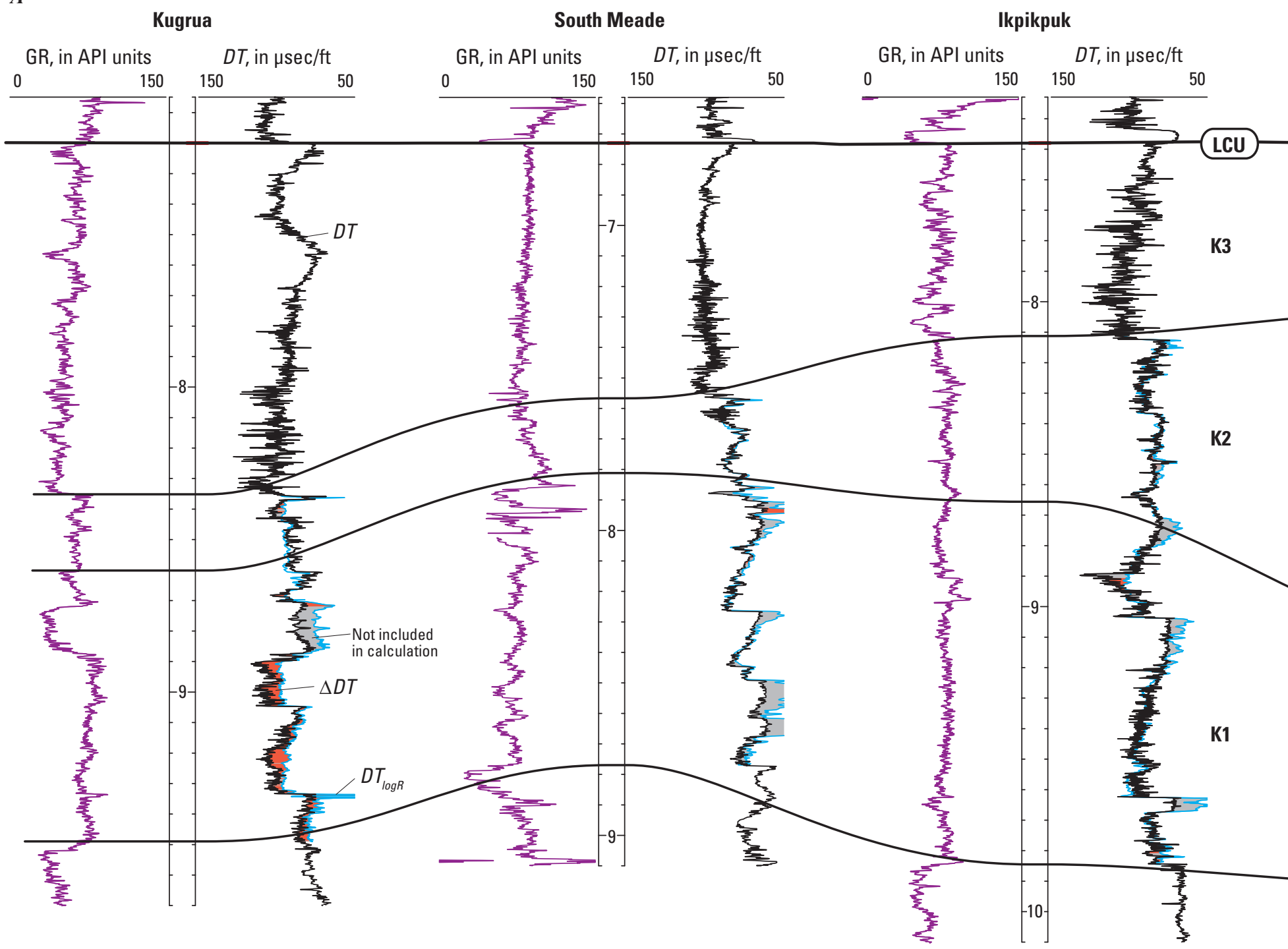

Figure 12. Well logs from cross section $A-A^{\prime}$ illustrating regional change in $\triangle D T$ (highlighted in red) related to location in Kingak Shale K1-K3 sequence sets. Intervals with curve separation highlighted in gray have less than 60 percent shale content and were not included in the calculation of $\Delta D T$. Wireline-log measured depth ticks below kelly bushing are at 100-foot (ft) (30-meter) intervals. Cross section hung on the Lower Cretaceous unconformity (LCU). Location of cross section shown in figures 9 and 10. Abbreviations: API, American Petroleum Institute; DT, sonic travel time; GR, gamma ray; $\mu$ sec/ft, microseconds per foot. 
Kokoda 5

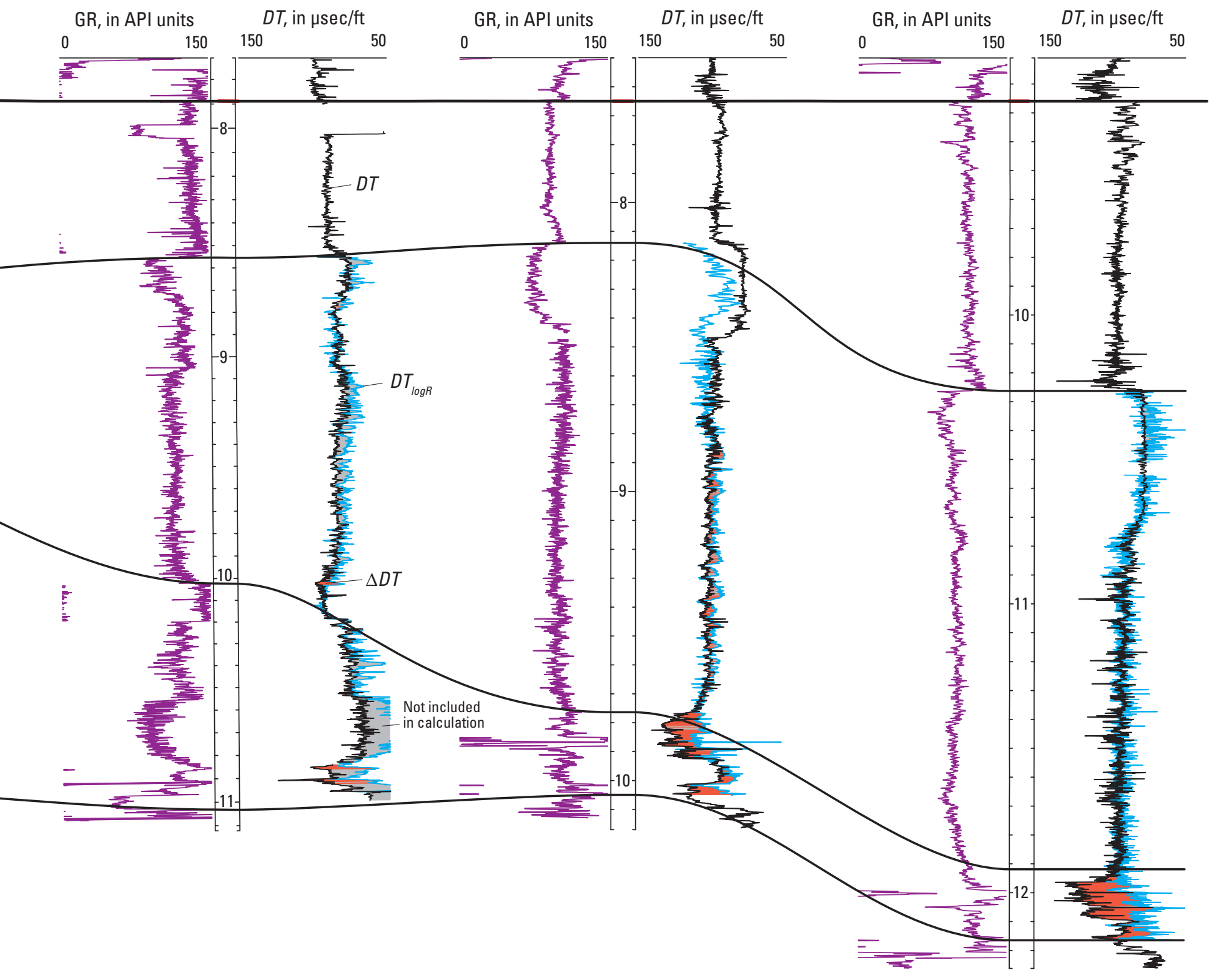

Figure 12. Well logs from cross section $A-A^{\prime}$ illustrating regional change in $\triangle D T$ (highlighted in red) related to location in Kingak Shale K1-K3 sequence sets. Intervals with curve separation highlighted in gray have less than 60 percent shale content and were not included in the calculation of $\triangle D T$. Wireline-log measured depth ticks below kelly bushing are at 100-foot (ft) (30-meter) intervals. Cross section hung on the Lower Cretaceous unconformity (LCU). Location of cross section shown in figures 9 and 10. Abbreviations: API, American Petroleum Institute; DT, sonic travel time; GR, gamma ray; $\mu$ sec/ft, microseconds per foot.-Continued 


\section{References Cited}

Beers, R.F., 1945, Radioactivity and organic content of some Paleozoic shales: American Association of Petroleum Geologists Bulletin, v. 29, no. 1, p. 1-22. [Also available at http://archives.datapages.com/data/bulletns/1944-48/data/ pg/0029/0001/0000/0001.htm.]

Bird, K.J., 1985, The framework geology of the North Slope of Alaska as related to oil-source rock correlations; Introductory papers, in Magoon, L.B., and Claypool, G.E., eds., Alaska North Slope oil-rock correlation study: American Association of Petroleum Geologists Studies in Geology 20, p. 3-29. [Also available at http://archives.datapages.com/data/ specpubs/geochem1/data/a031/a031/0001/0000/0003.htm.]

Bird, K.J., 2001, Alaska; A twenty-first-century petroleum province, chap. 9 of Downey, M.W., Threet, J.C., and Morgan, W.A., eds., Petroleum provinces of the twenty-first century: American Association of Petroleum Geologists Memoir 74, p. 137-165. [Also available at http://archives. datapages.com/data/specpubs/memoir74/m74ch09/ m74ch09.htm.]

Bird, K.J., and Houseknecht, D.W., 2011, Geology and petroleum potential of the Arctic Alaska petroleum province, chap. 32 of Spencer, A.M., Embry, A.F., Gautier, D.L., Stoupakova, A.V., and Sørensen, Kai, eds., Arctic petroleum geology: Geological Society of London Memoirs, v. 35, p. 485-499. [Also available at http://dx.doi.org/10.1144/ M35.32.]

Bowman, Thomas, 2010, Direct method for determining organic shale potential from porosity and resistivity logs to identify possible resource plays: American Association of Petroleum Geologists Search and Discovery Article 110128 [adapted from oral presentation at AAPG Annual Convention, New Orleans, Louisiana, April 11-14, 2010], 34 p., accessed November 24, 2014, at http://www.searchanddiscovery.com/documents/2010/110128bowman/ndx bowman.pdf.

Carman, G.J., and Hardwick, Peter, 1983, Geology and regional setting of the Kuparuk oil field, Alaska: American Association of Petroleum Geologists Bulletin, v. 67, no. 6, p. 1014-1031. [Also available at http://archives.datapages.com/data/bulletns/ 1982-83/data/pg/0067/0006/1000/1014.htm.]

Claypool, G.E., and Magoon, L.B., 1985, Comparison of oil-source rock correlation data for Alaskan North SlopeTechniques, results, and conclusions, in Magoon, L.B., and Claypool, G.E., eds., Alaska North Slope oil-rock correlation study: American Association of Petroleum Geologists Studies in Geology 20, p. 49-81. [Also available at http://archives.datapages.com/data/specpubs/geochem1/ data/a031/a031/0001/0000/0049.htm.]
Dellenbach, J., Espitalie, J., and Lebreton, F., 1983, Source rock logging: Transactions of the 8th European Society of Petrophysicists and Well Log Analysts Symposium, paper D.

Gradstein, F.M., and Ogg, J.G., 1996, A Phanerozoic time scale: Episodes, v. 19, no. 1-2, p. 3-5.

Gradstein, F.M., Ogg, J.G., Smith, A.G., Bleeker, W., and Lourens, L.J., 2004, A new geologic time scale, with special reference to Precambrian and Neogene: Episodes, v. 27, no. 2, p. 83-100.

Hayba, D.O., Bird, K.J., and Garrity, C.P., 2002, Subsurface oil and gas indications in and adjacent to the NPRA, chap. 5 of Houseknecht, D.W., ed., National Petroleum Reserve, Alaska (NPRA) core images and well data: U.S. Geological Survey Digital Data Series DDS-75 (4 CD-ROM).

Hood, A., Gutjahr, C.C.M., and Heacock, R.L., 1975, Organic metamorphism and the generation of petroleum: American Association of Petroleum Geologists Bulletin, v. 59, no. 6, p. 986-996. [Also available at http://archives.datapages.com/ data/bulletns/1974-76/data/pg/0059/0006/0950/0986.htm.]

Houseknecht, D.W., and Bird, K.J., 2004, Sequence stratigraphy of the Kingak Shale (Jurassic-Lower Cretaceous), National Petroleum Reserve in Alaska: American Association of Petroleum Geologists Bulletin, v. 88, no. 3, p. 279-302. [Also available at http://archives.datapages. com/data/bulletns/2004/03mar/0279/0279.htm.]

Houseknecht, D.W., Bird, K.J., and Garrity, C.P., 2012, Assessment of undiscovered petroleum resources of the Arctic Alaska Petroleum Province: U.S. Geological Survey Scientific Investigations Report 2012-5147, 26 p. [Also available at http://pubs.usgs.gov/sir/2012/5147/.]

Houseknecht, D.W., Rouse, W.A., and Garrity, C.P., 2012, Arctic Alaska shale-oil and shale-gas resource potential: Arctic Technology Conference, Houston, Texas, December 3-5, 2012, Offshore Technology Conference, 4 p. [Also available at http://dx.doi.org/10.4043/23796-MS.]

Houseknecht, D.W., Rouse, W.A., Garrity, C.P., Whidden, K.J., Dumoulin, J.A., Schenk, C.J., Charpentier, R.R., Cook, T.A., Gaswirth, S.B., Kirschbaum, M.A., and Pollastro, R.M., 2012, Assessment of potential oil and gas resources in source rocks of the Alaska North Slope, 2012: U.S. Geological Survey Fact Sheet 2012-3013, 2 p., accessed November 24, 2014, at http://pubs.usgs.gov/fs/2012/3013/.

Houseknecht, D.W., Rouse, W.A., Paxton, S.T., Mars, J.C., and Fulk, Bryant, 2014, Upper Devonian-Mississippian stratigraphic framework of the Arkoma Basin and distribution of potential source-rock facies in the WoodfordChattanooga and Fayetteville-Caney shale-gas systems: American Association of Petroleum Geologists Bulletin, v. 98, no. 9, p. 1739-1759. [Also available at http://dx.doi.org/ 10.1306/03031413025.] 
Hubbard, R.J., Edrich, S.P., and Rattey, R.P., 1987, Geologic evolution and hydrocarbon habitat of the 'Arctic Alaska microplate': Marine and Petroleum Geology, v. 4, no. 1, p. 2-34. [Also available at http://dx.doi.org/10.1016/ 0264-8172(87)90019-5.]

Lerand, Monti, 1973, Beaufort Sea, in McCrossan, R.G., ed., The future petroleum provinces of Canada-Their geology and potential: Canadian Society of Petroleum Geologists Memoir 1, p. 315-386.

Magoon, L.B., and Claypool, G.E., 1984, The Kingak Shale of northern Alaska-Regional variations in organic geochemical properties and petroleum source rock quality: Organic Geochemistry, v. 6, p. 533-542. [Also available at http://dx.doi.org/10.1016/0146-6380(84)90076-7.]

Magoon, L.B., Lillis, P.G., Bird, K.J., Lampe, C., and Peters, K.E., 2003, Alaskan North Slope petroleum systems: U.S. Geological Survey Open-File Report 03-324, 3 sheets, accessed November 24, 2014, at http://pubs.usgs.gov/of/ 2003/of03-324/.

Masterson, W.D., IV, 2001, Petroleum filling history of central Alaskan North Slope fields: University of Texas at Dallas, unpublished Ph.D. dissertation, $222 \mathrm{p}$.

Masterson, W.D., and Paris, C.E., 1987, Depositional history and reservoir description of the Kuparuk River Formation, North Slope, Alaska, in Tailleur, Irv, and Weimer, Paul, eds., Alaskan North Slope Geology: Pacific Section, Society of Economic Paleontologists and Mineralogists and Alaska Geological Society 50, v. 1, p. 95-107.

Meissner, F.F., 1978, Petroleum geology of the Bakken Formation, Williston basin, North Dakota and Montana, in The economic geology of the Williston basin: Montana Geological Society, 24th annual Williston Basin Symposium, Billings, Montana, September 24-27, 1978, p. 207-227.

Meyer, B.L., and Nederlof, M.H., 1984, Identification of source rocks on wireline logs by density/resistivity and sonic transit time/resistivity cross plots: American Association of Petroleum Geologists Bulletin, v. 68, no. 2, p. 121-129. [Also available at http://archives.datapages.com/data/bulletns/ 1984-85/data/pg/0068/0002/0100/0121.htm.]

Mull, C.G., Houseknecht, D.W., and Bird, K.J., 2003, Revised Cretaceous and Tertiary stratigraphic nomenclature in the Colville Basin, northern Alaska: U.S. Geological Survey Professional Paper 1673, 51 p., accessed November 24, 2014, at http://pubs.usgs.gov/pp/p1673/p1673.pdf.

Nixon, R.P., 1973, Oil source beds in Cretaceous Mowry Shale of northwestern interior United States: American Association of Petroleum Geologists Bulletin, v. 57, no. 1, p. 136-161. [Also available at http:/archives.datapages.com/data/bulletns/ 1971-73/data/pg/0057/0001/0100/0136.htm.]
Passey, Q.R., Bohacs, K.M., Esch, W.L., Klimentidis, R., and Sinha, S., 2010, From oil-prone source rock to gasproducing shale reservoir-Geologic and petrophysical characterization of unconventional shale-gas reservoirs: International Oil and Gas Conference and Exhibition, Beijing, China, June 8-10, 2010, Society of Petroleum Engineers Paper 131350, 29 p.

Passey, Q.R., Creaney, S., Kulla, J.B., Moretti, F.J., and Stroud, J.D., 1990, A practical model for organic richness from porosity and resistivity logs: American Association of Petroleum Geologists Bulletin, v. 74, no. 12, p. 1777-1794. [Also available at http://archives.datapages.com/data/bulletns/ 1990-91/data/pg/0074/0012/0000/1777.htm.]

Peters, K.E., Magoon, L.B., Bird, K.J., Valin, Z.C., and Keller, M.A., 2006, North Slope, Alaska-Source-rock distribution, richness, thermal maturity, and petroleum charge: American Association of Petroleum Geologists Bulletin, v. 90, no. 2, p. 261-292. [Also available at http://dx.doi.org/10.1306/09210505095.]

Premuzic, E.T., Gaffney, J.S., and Manowitz, B., 1986, The importance of sulfur isotope ratios in the differentiation of Prudhoe Bay crude oils: Journal of Geochemical Exploration, v. 26, no. 2, p. 151-159. [Also available at http://dx.doi.org/10.1016/0375-6742(86)90064-6.]

Schmoker, J.W., 1979, Determination of organic content of Appalachian Devonian shales from formation-density logs: American Association of Petroleum Geologists Bulletin, v. 63, no. 9, p. 1504-1509. [Also available at http://archives.datapages.com/data/bulletns/1977-79/ data/pg/0063/0009/1500/1504.htm.]

Schmoker, J.W., 1981, Determination of organic-matter content of Appalachian Devonian shales from gammaray logs: American Association of Petroleum Geologists Bulletin, v. 65, no. 7, p. 1285-1298. [Also available at http://archives.datapages.com/data/bulletns/1980-81/data/ pg/0065/0007/1250/1285.htm.]

Schmoker, J.W., and Hester, T.C., 1989, Oil generation inferred from formation resistivity-Bakken Formation, Williston basin, North Dakota: Transactions of the Thirtieth Society of Petrophysicists and Well Log Analysts Annual Logging Symposium, paper H.

Sedivy, R.A., Penfield, I.E., Halpern, H.I., Drozd, R.J., Cole, G.A., and Burwood, R., 1987, Investigation of source rock-crude oil relationships in the northern Alaska hydrocarbon habitat, in Tailleur, Irv, and Weimer, Paul, eds., Alaskan North Slope Geology: Pacific Section, Society of Economic Paleontologists and Mineralogists and Alaska Geological Society 50, v. 1, p. 169-179.

Seifert, W.K., Moldowan, J.M., and Jones, R.W., 1980, Application of biological marker chemistry to petroleum exploration: Proceedings of the 10th World Petroleum Congress, Bucharest, Romania, September 9-14, 1979, p. 425-440. 
Sondergeld, C.H., Newsham, K.E., Comisky, J.T., Rice, M.C., and Rai, C.S., 2010, Petrophysical considerations in evaluating and producing shale gas resources: Society of Petroleum Engineers Unconventional Gas Conference, Pittsburgh, Pennsylvania, February 23-25, 2010, Society of Petroleum Engineers Paper 131768, 34 p.

Threlkeld, C.N., Obuch, R.C., and Gunther, G.L., 2000, Organic geochemistry data of Alaska: U.S. Geological Survey Digital Data Series DDS-59, accessed November 24, 2014, at http://pubs.usgs.gov/dds/dds-059/.

Tissot, B.P., and Welte, D.H., 1984, Petroleum formation and occurrence: New York, Springer-Verlag, 699 p. [Also available at http://dx.doi.org/10.1007/978-3-642-96446-6.] 


\section{Appendix 1. Workflow for Calculating Key Parameters}

The following workflow was compiled using IHS Kingdom ${ }^{\circledR}$ version 8.8 software with the EarthPAK ${ }^{\circledR}$ module. This workflow assumes that a project has already been populated with well locations, digital gamma-ray, resistivity, and sonic wireline-log data in LAS format, and formation tops that bound the stratigraphic interval of interest. For instructions on how to input these data, the reader is referred to the IHS Kingdom ${ }^{\circledR}$ version 8.8 software help files. This workflow uses input parameters specific to the Alaska North Slope Kingak Shale that may not be applicable to all shale plays.

\section{Calculating Shale Volume $\left(V_{s h}\right)$}

Note: The Petrophysics module is available with an EarthPAK license.

1. From the Logs menu, select Petrophysics... to proceed to the Petrophysics dialog box.

2. In the Quick-Look Analysis Navigator window, select Zone-related Parameters.

3. In the Zone-related Parameters window, from the Select an Existing Zone drop-down menu, select Borehole (Public). Under Select Lithology and Porosity Model, from the Reservoir Lithology drop-down menu, select the appropriate reservoir lithology (sandstone in this example). Accept all other defaults.

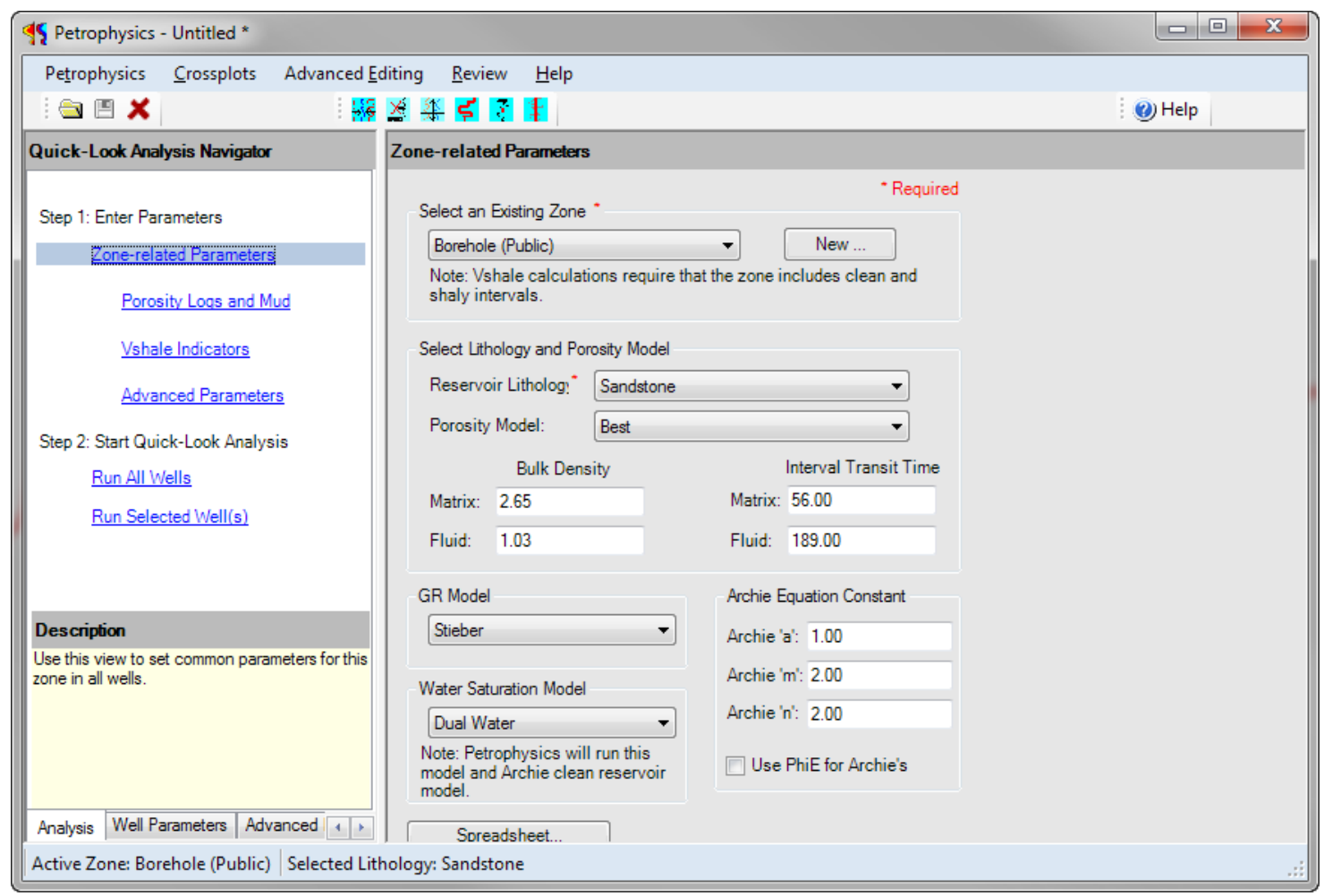


4. In the Quick-Look Analysis Navigator, under Zone-related Parameters, select Vshale Indicators. Calculated values for clean and shale baselines for gamma-ray (GR) and spontaneous potential (SP) are displayed; these may be accepted or manually adjusted.

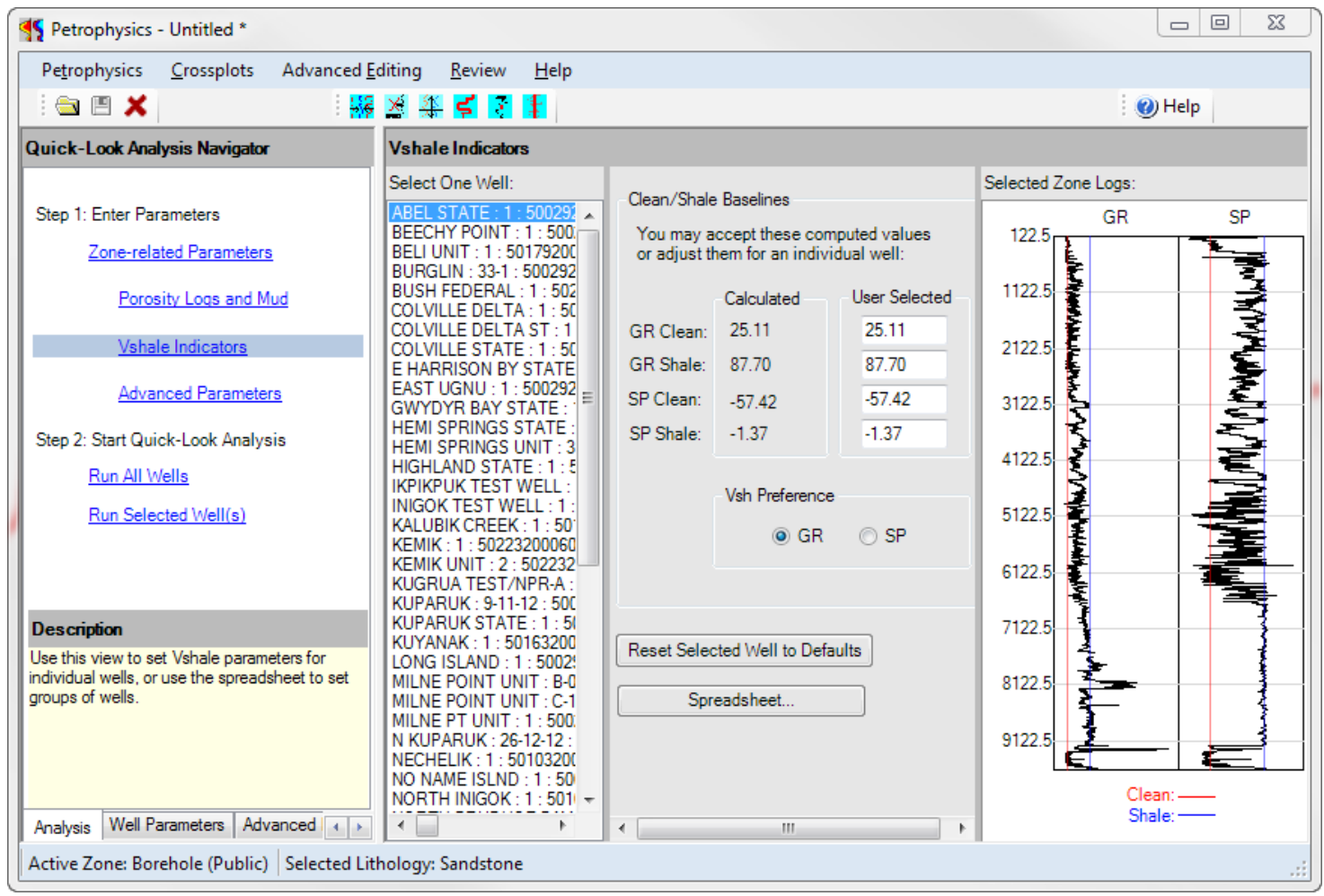

5. In the Quick-Look Analysis Navigator, select Run All Wells to proceed to the Select Logs to Save dialog box.

6. Select VShale from the curve selection window.

7. Under Save Options, toggle Create New Curves Only and accept the default prefix of SMT.

8. Click OK.

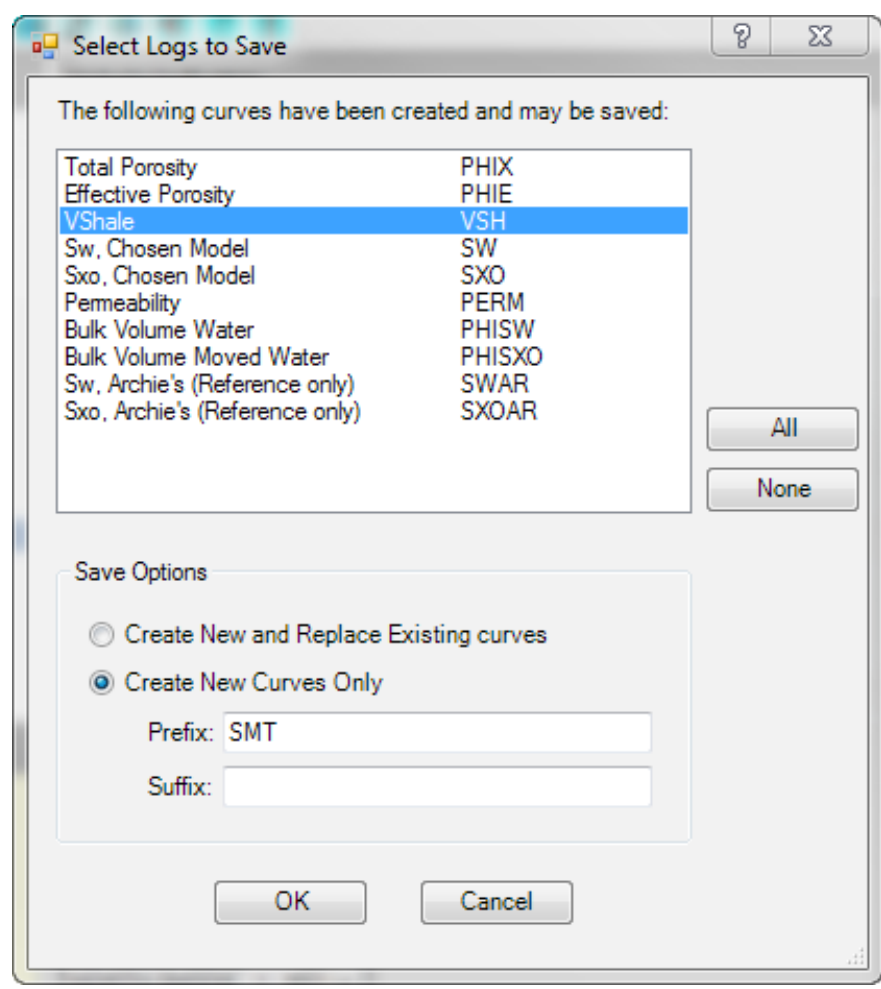




\section{Calculating $\log R$}

1. From the Logs menu, select Calculations $\rightarrow$ Equation to proceed to the Select or Enter an Equation dialog box.

2. In the Equation Category window, type Other.

3. In the Equation window, type LOGR=. In the Functions window below, double click on $\mathbf{L O G 1 0 ( x )}$ to place it in the equation and replace (x) with $\mathbf{R}$. The resulting equation should read LOGR=LOG10(R).

4. In the Description window, type LogR from resistivity.

5. Click Next $>$ to proceed to the Assign Variables dialog box.

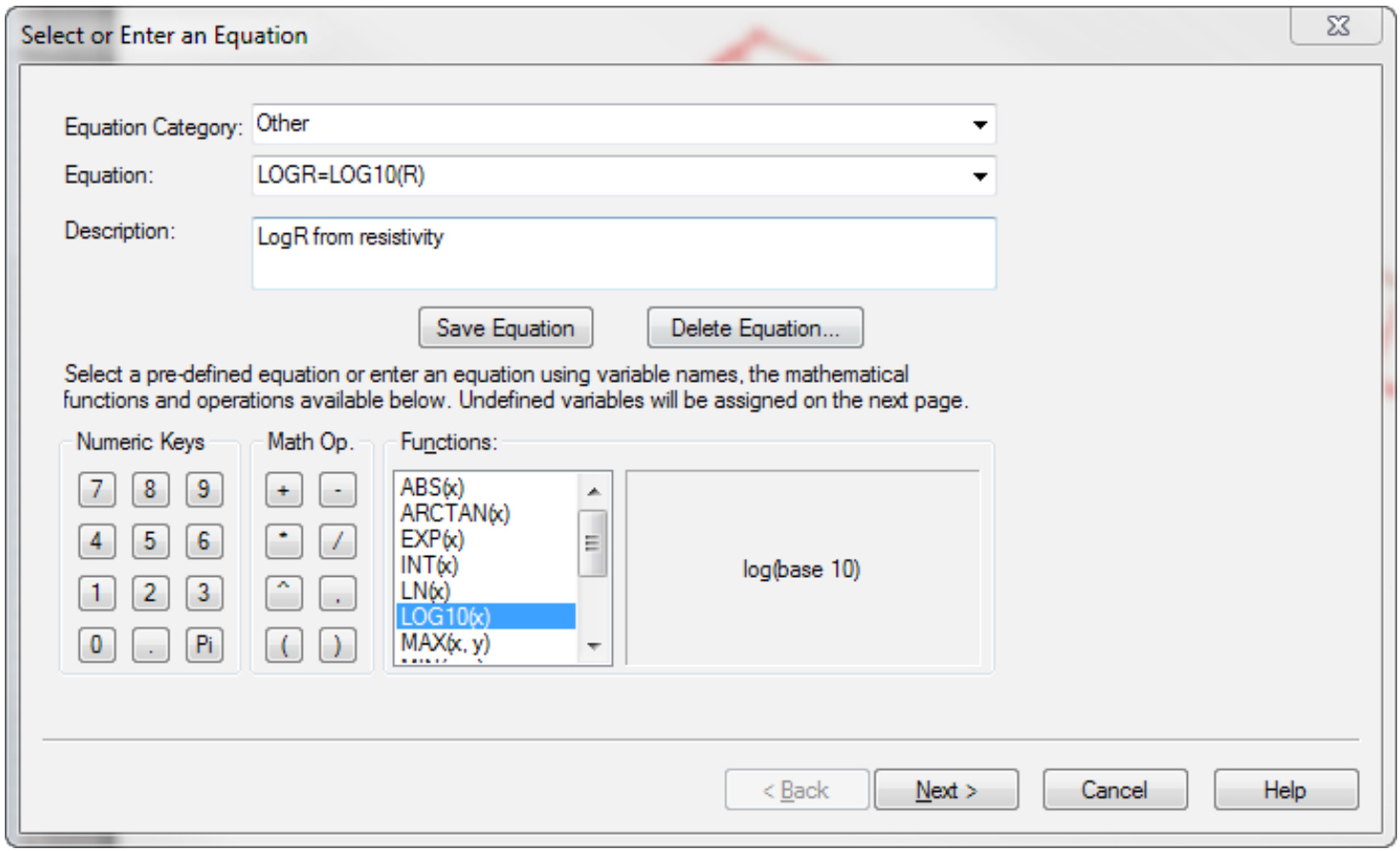


6. To assign $\mathbf{R}$ to the resistivity (RILD) log curve, in the Select the Variable to Assign window, select $\mathbf{R}$; then toggle on Log Curves, and select RILD from the drop-down menu and click Assign.

7. Click Next $>$ to proceed to the Depth Range Selection dialog box.

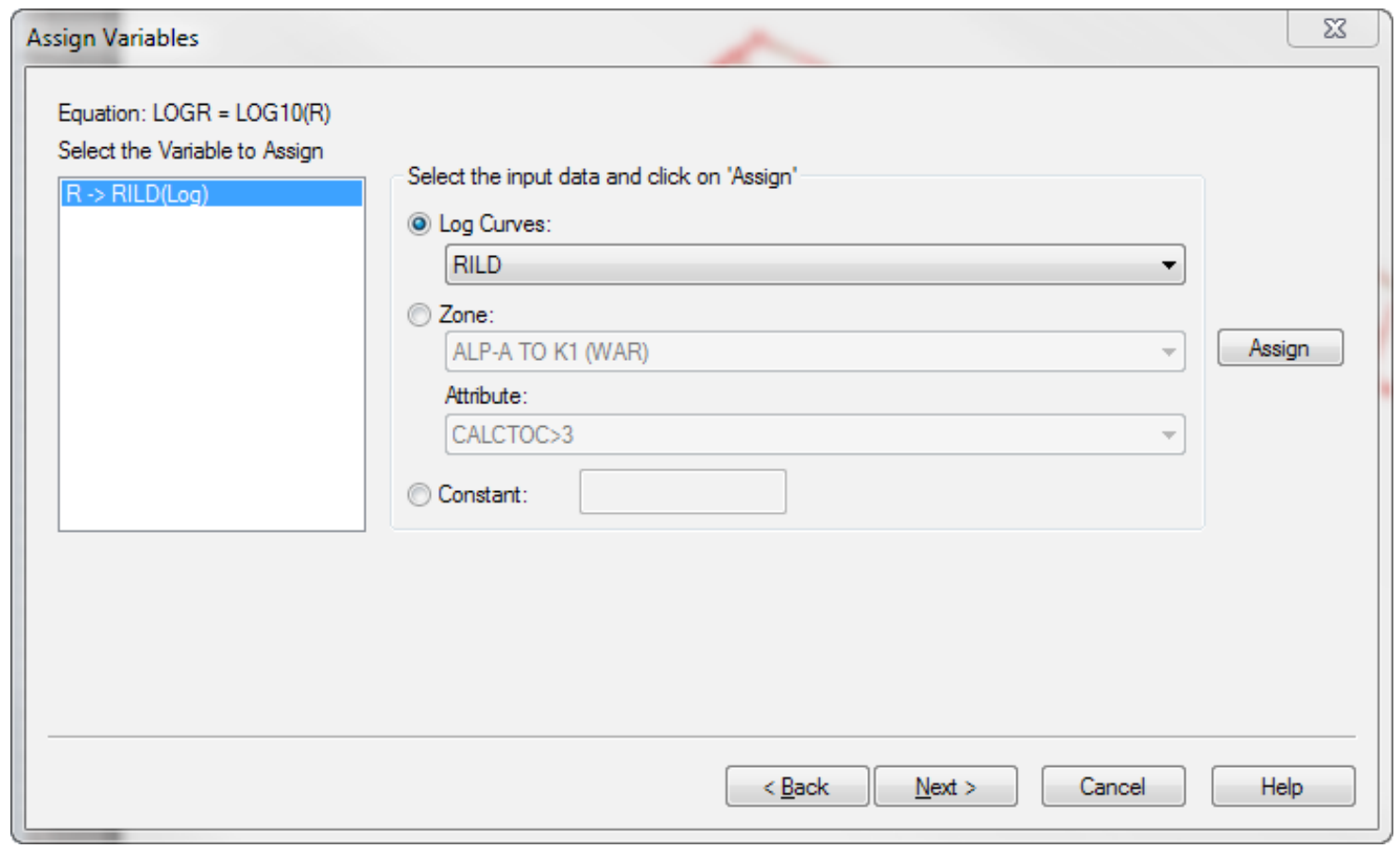

8. Toggle on by Zone Intervals and select Borehole (Public) from the drop-down menu.

9. Click Next $>$ to proceed to the Output dialog box.

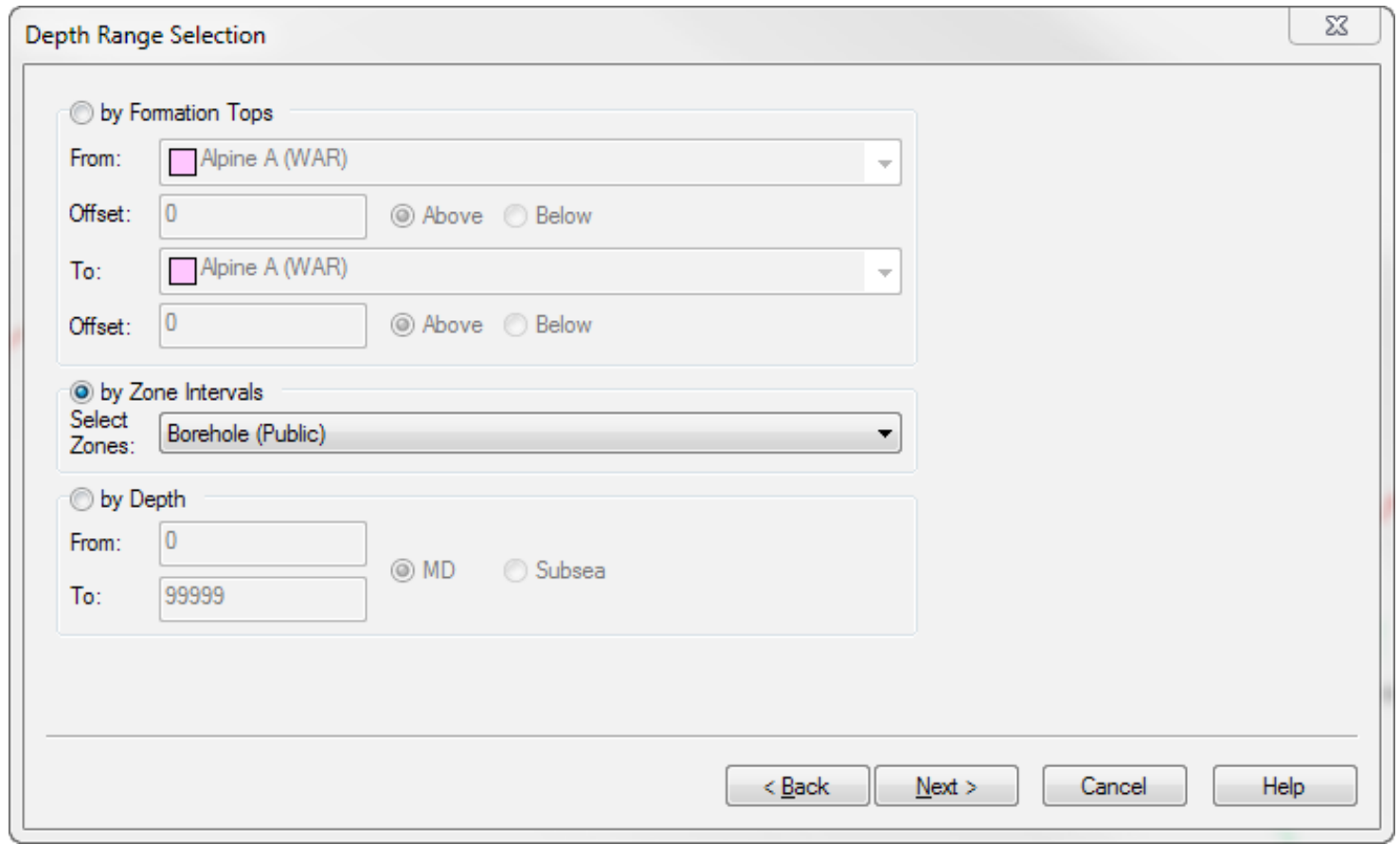


10. In the Output Log Curve Name window, type LOGR.

11. From the Output Log Curve Type drop-down menu, select Other.

12. Toggle on Create new log curve and replace existing curve.

13. Click Finish.

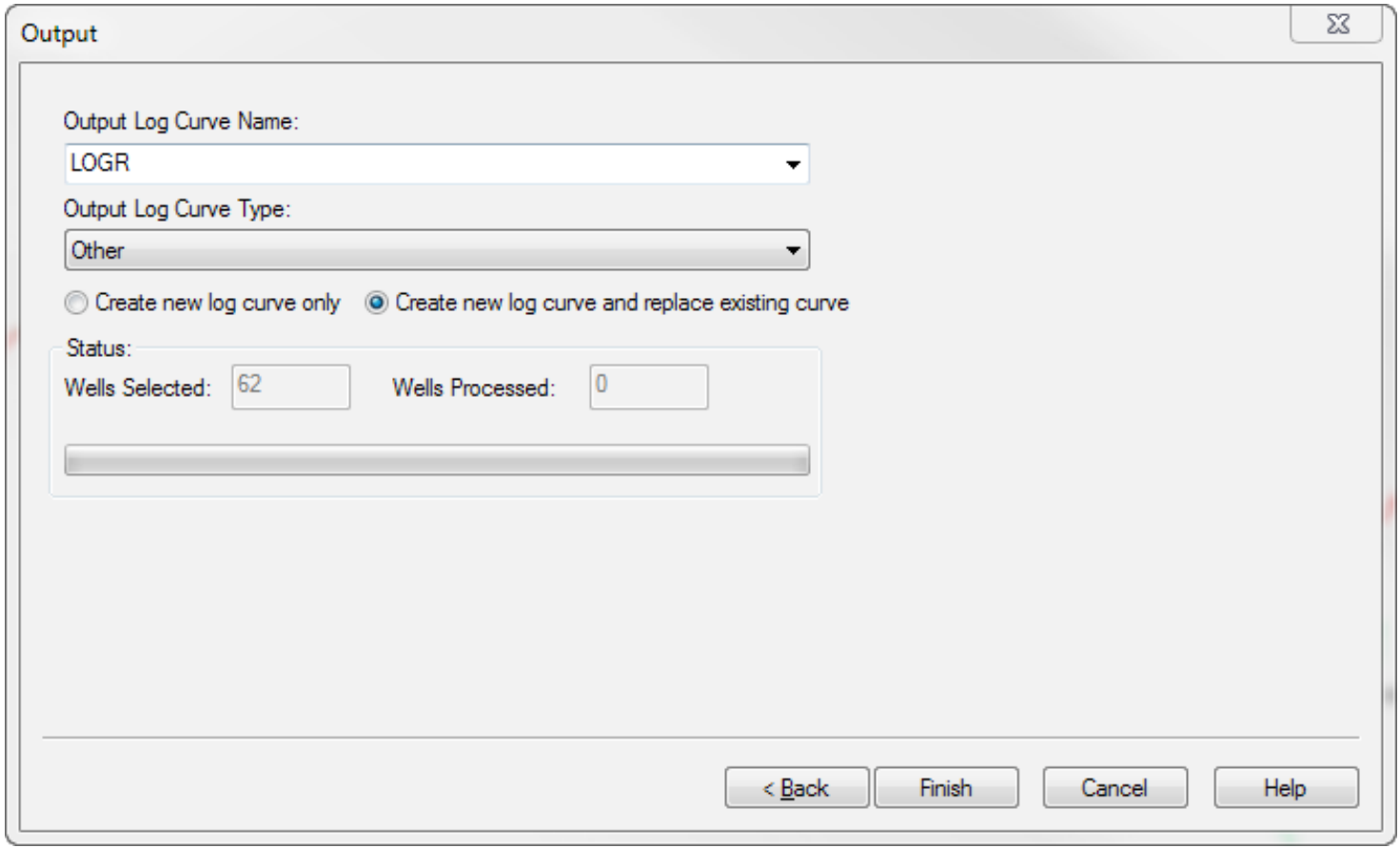




\section{Creating a Cross Plot of $\log R$ versus DT}

Note: The following exercise assumes that the user has predefined zones within the interval of interest. For these exercises, the K1 TO KBASE zone is the interval that is assessed for probable source rock potential and the

K2 TO K1 zone is the assumed non-source rock interval used to create baseline sonic and resistivity data.

1. From the Tools menu, select Crossplot $\rightarrow$ New to proceed to the Select Data dialog box.

2. In the Category window, select Log.

3. In the Attributes drop-down menu, select a well that contains gamma-ray, sonic, and resistivity log curves and for which you have calculated VSH and LOGR.

4. In the Attributes window, select the LOGR curve; from the Axis/Filter window, select $\mathbf{X}$ and click $>$.

5. In the Attributes window, select the DT curve; from the Axis/Filter window, select $\mathbf{Y}$ and click $>$.

6. In the Attributes window, select the SMTVSH curve; from the Axis/Filter window, select Filter and click $>$. In the Min Value window, type $\mathbf{0 . 6}$ and keep the default Max Value.

7. Click Depth Range to proceed to the Crossplot Depth Range Selection dialog box.

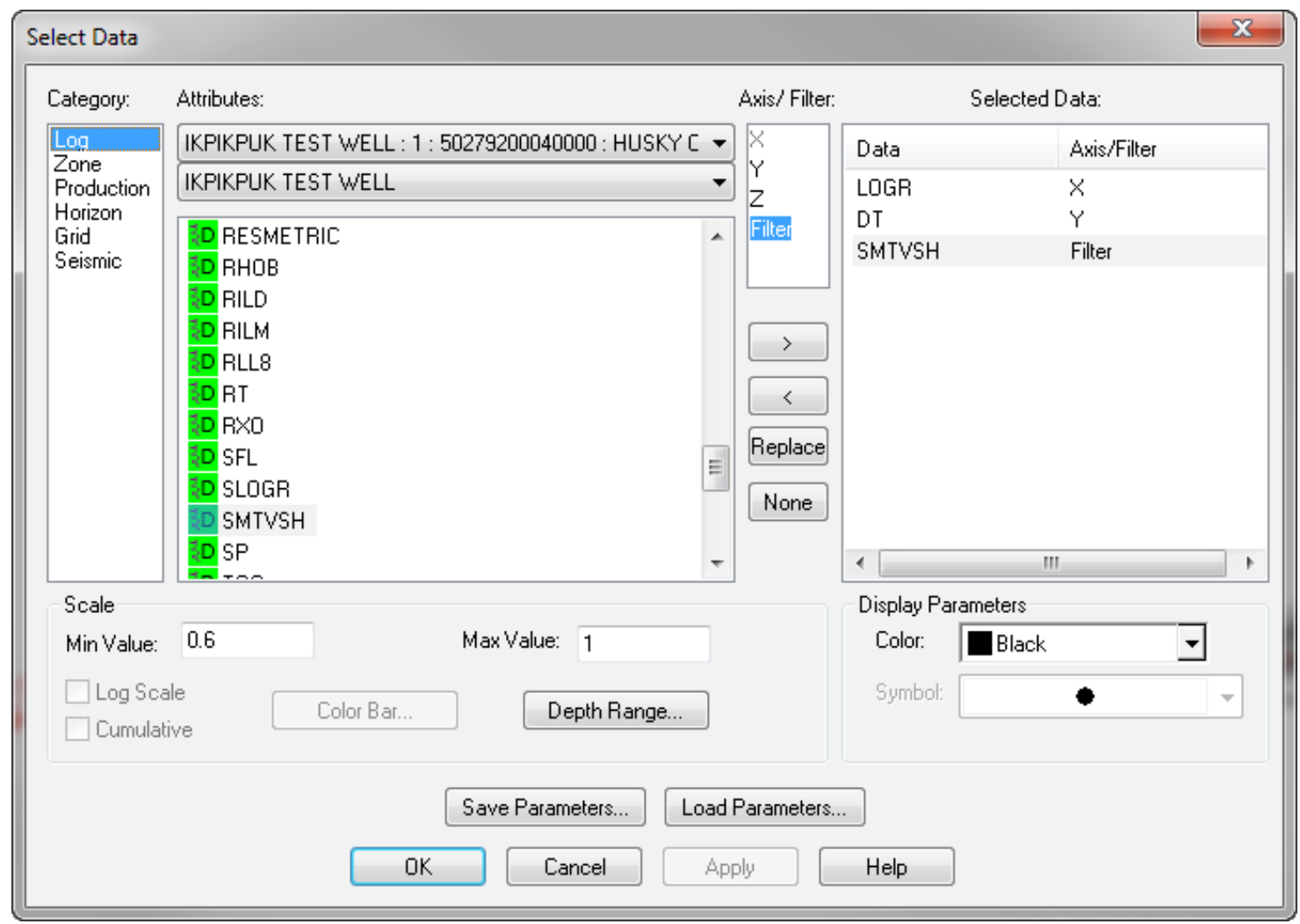


8. Toggle on By Zone Intervals and select the assumed non-source rock interval zone.

9. Click OK to return to proceed to the Select Data dialog box.

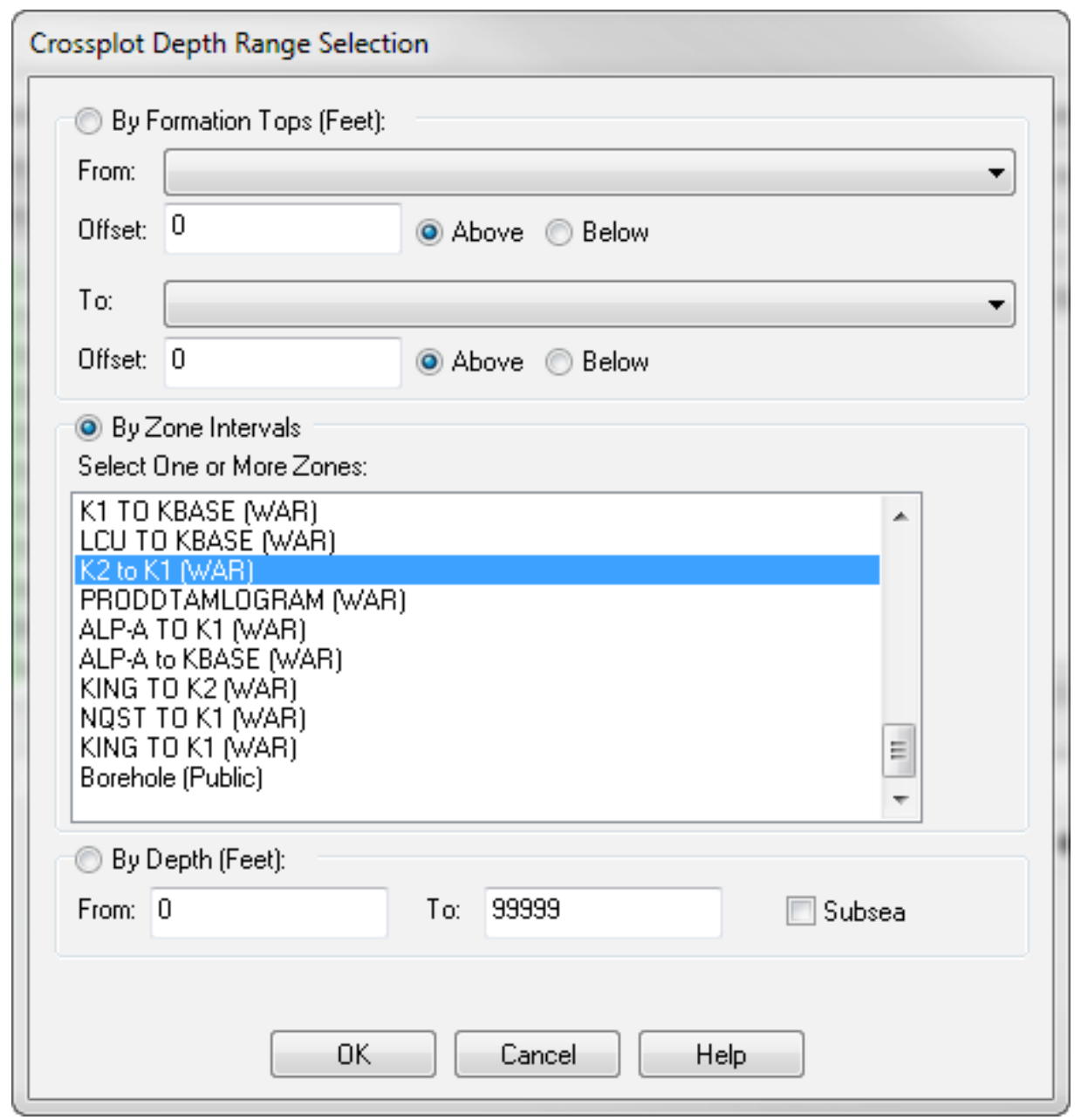

10. Click OK to proceed to the Crossplot window. 


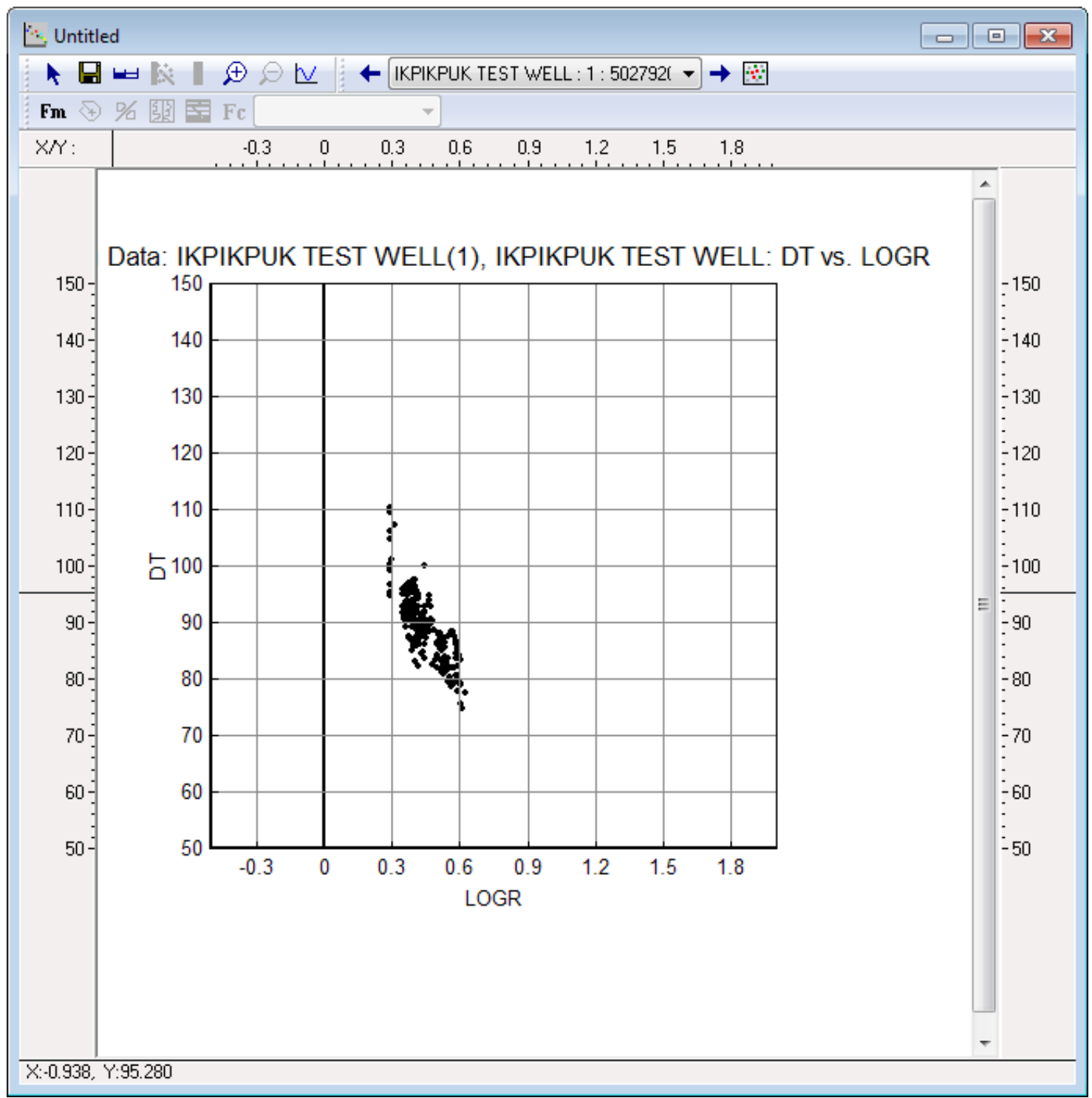

11. Click on the regression icon $\stackrel{V}{V}$ to proceed to the Regression dialog box. 
12. Under Regression Method, toggle on Numerical Regression.

13. Under Equation, toggle on Polynomial and Reduced Major Axis (RMA).

14. Click OK to return to the Crossplot window.

\begin{tabular}{|c|c|c|c|}
\hline \multicolumn{3}{|l|}{ Regression } & $\Sigma 3$ \\
\hline \multicolumn{3}{|l|}{ Regression Method } & Digitize Regression \\
\hline $\begin{array}{l}\text { Equation } \\
\text { (0) Polynomial } \\
\text { Drder (1 to 6): } 1 \text { Y } \mathrm{Y} \text {, } \mathrm{X} \text { on } \mathrm{Y}\end{array}$ & educed & Axis (RK & \\
\hline \multicolumn{4}{|l|}{ Exponential } \\
\hline Cancel & Apply & Help & \\
\hline
\end{tabular}




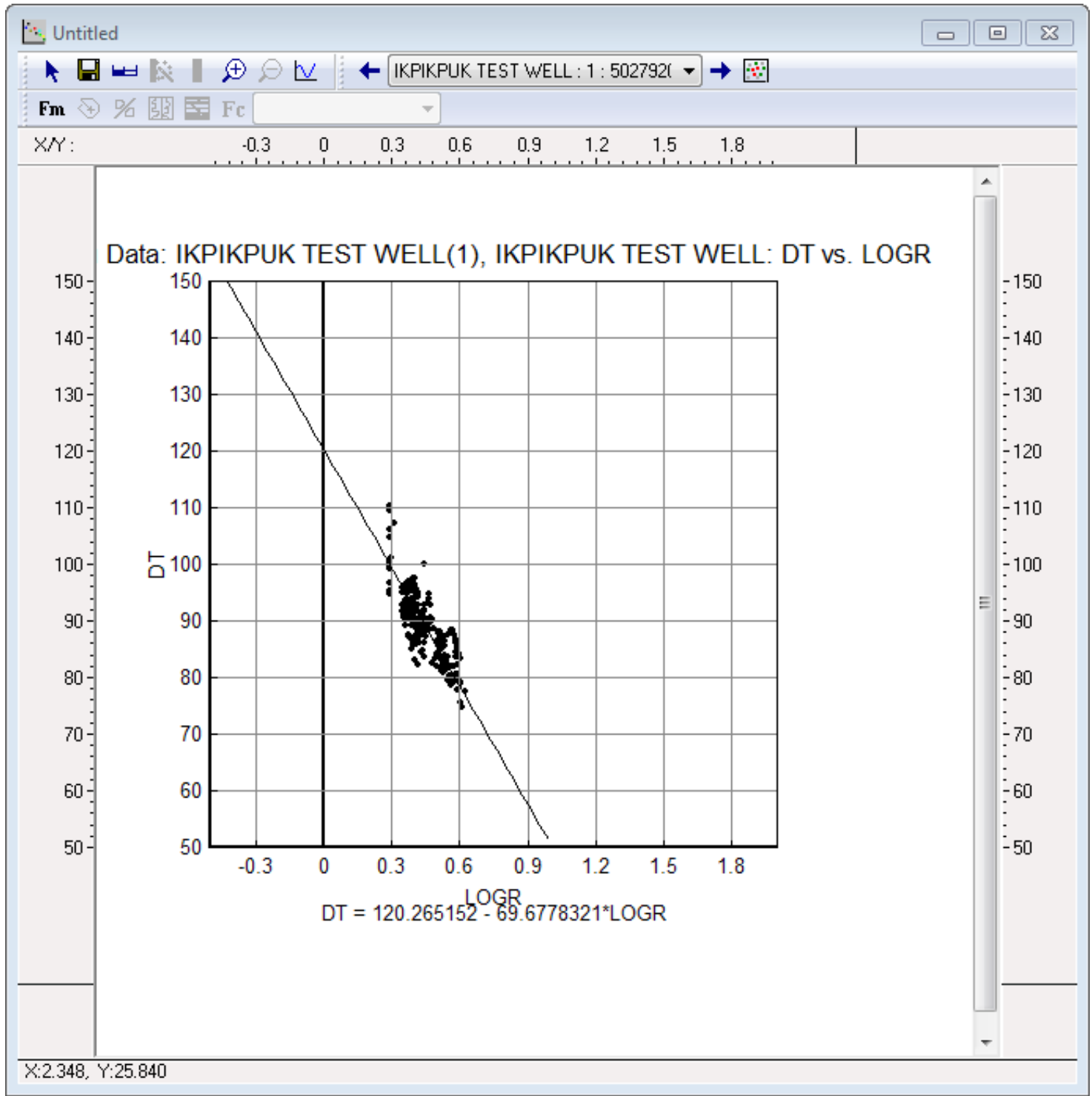

15. The regression equation is shown under the $\mathrm{x}$-axis. Record the slope and intercept of the regression line for each well in order to calculate DTLOGR. 


\section{Calculating $D T_{\text {logR }}(D T L O G R)$}

Note: Calculation of $D T_{\log R}$ must be done on a well-by-well basis. When using this workflow, make sure that only one well is selected in the project, otherwise the calculation will be applied to all wells selected.

1. From the Logs menu, select Calculations $\rightarrow$ Equation to proceed to the Select or Enter an Equation dialog box.

2. In the Equation Category window, type Other.

3. In the Equation window, type DTLOGR=B-M*LOGR.

4. In the Description window, type DTLOGR from Crossplot of LogR vs. DT.

5. Click Next $>$ to proceed to the Assign Variables dialog box.

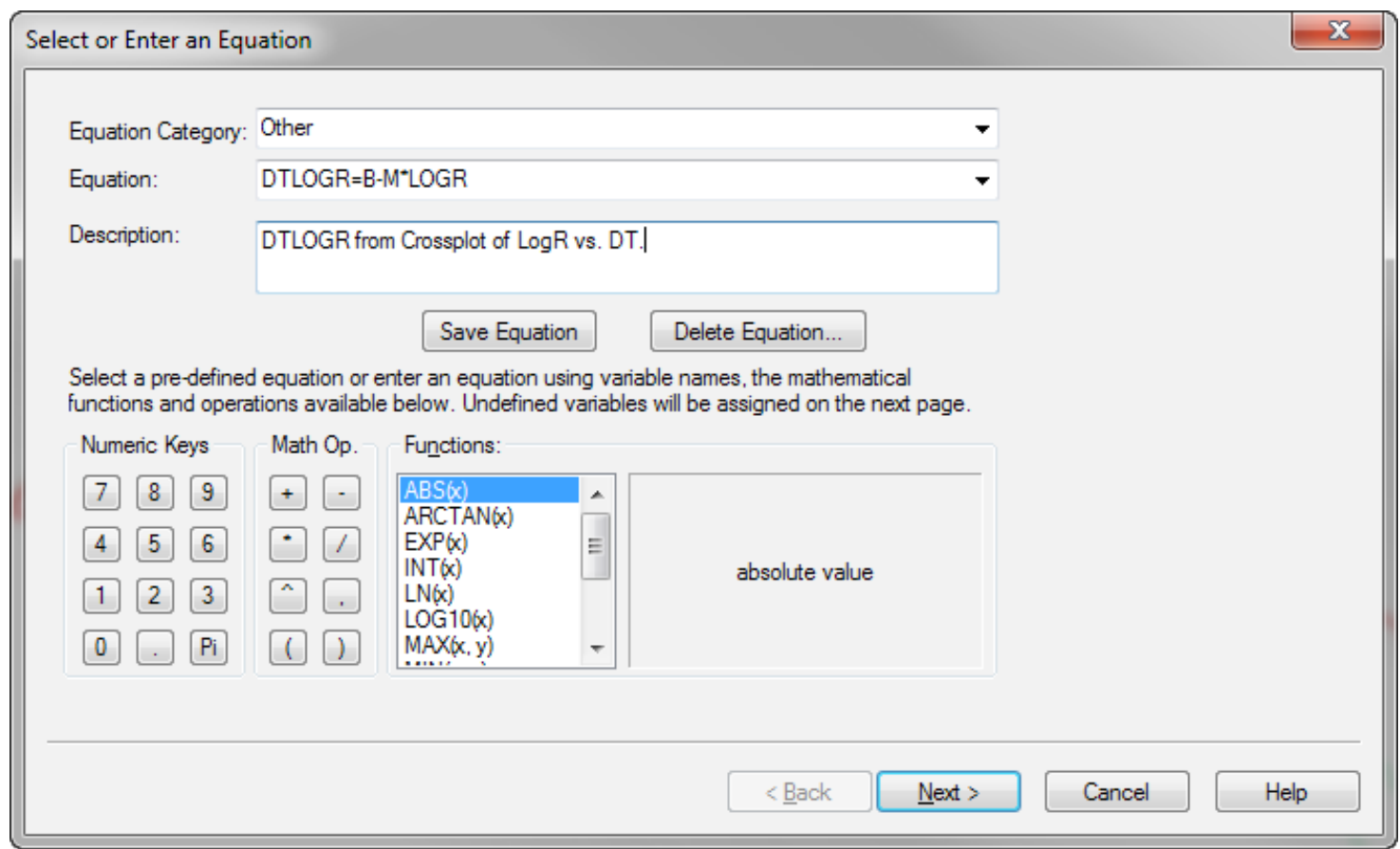


6. Assign $\mathbf{B}$ to the $\mathbf{y}$ intercept of the regression equation for the well by selecting $\mathbf{B}$ in the Select the Variable to Assign window, toggling on Constant, entering the intercept value in the window, and clicking Assign.

7. Assign LOGR to the LOGR log curve by selecting LOGR in the Select the Variable to Assign window, toggling on Log Curves, selecting LOGR from the drop-down menu, and clicking Assign.

8. Assign $\mathbf{M}$ to the slope of the regression equation for the well by selecting $\mathbf{M}$ in the Select the Variable to Assign window, toggling on Constant, entering the slope value in the window, and clicking Assign.

9. Click Next $>$ to proceed to the Depth Range Selection dialog box.

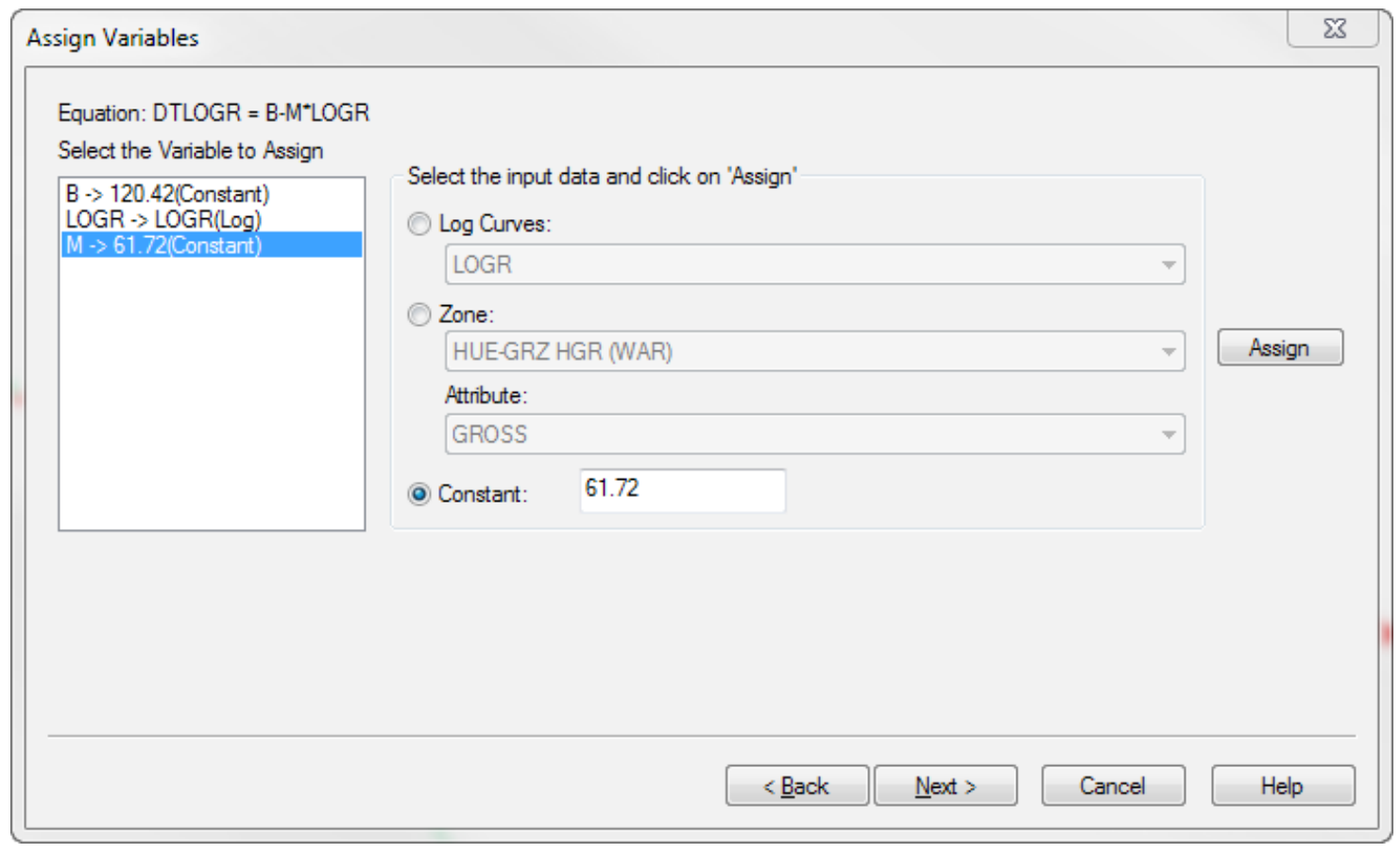


10. Toggle on by Zone Intervals and select the zone to be assessed for probable source rock potential from the drop-down menu.

11. Click Next $>$ to proceed to the Output dialog box.

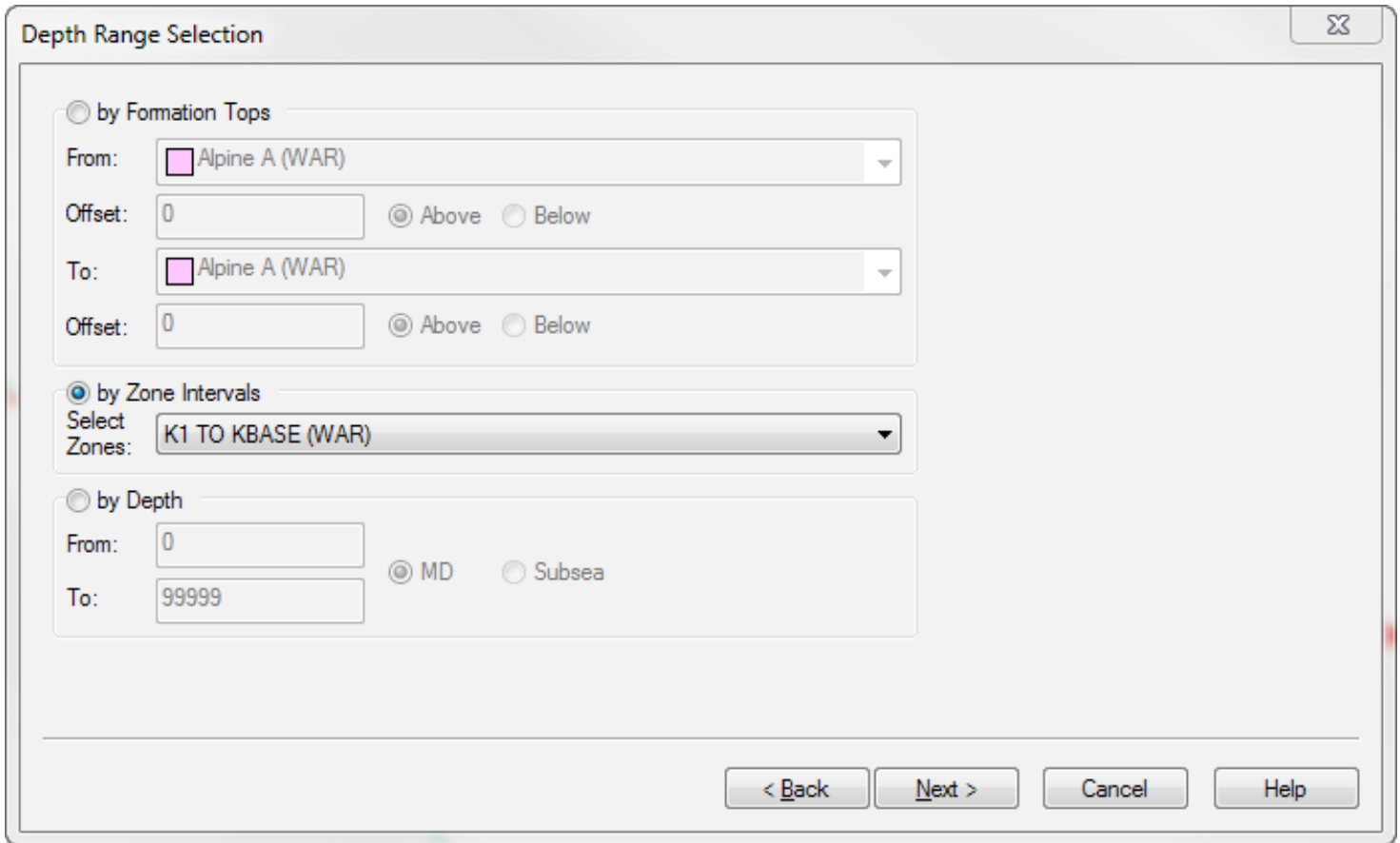

12. In the Output Log Curve Name window, type DTLOGR.

13. In the Output Log Curve Type window, select Other from the drop-down menu.

14. Toggle on Create new log curve and replace existing curve.

15. Click Finish.

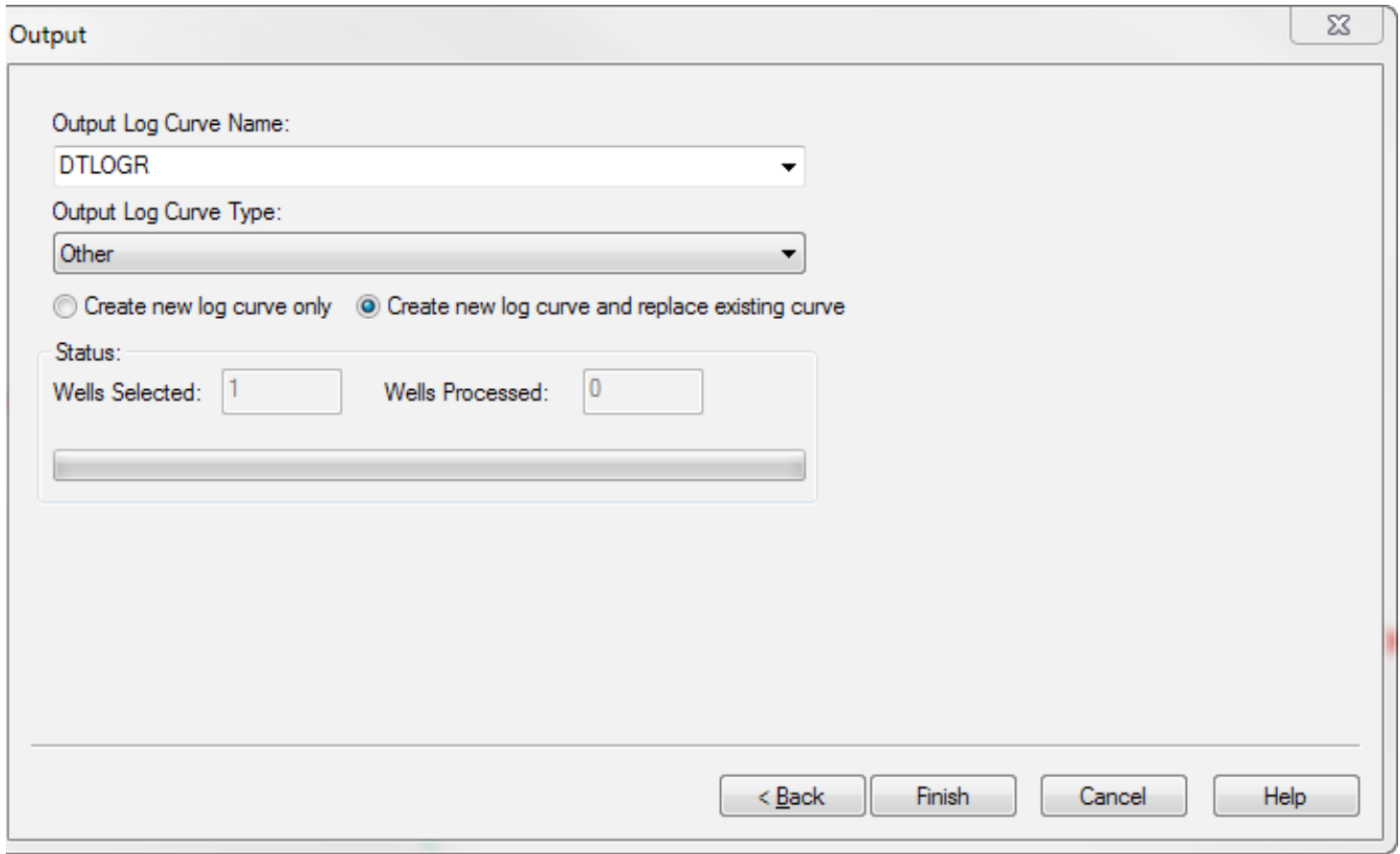




\section{Calculating $\triangle D T$ Curve Separation}

1. From the Logs menu, select Calculations $\rightarrow$ Equation to proceed to the Select or Enter an Equation dialog box.

2. In the Equation Category window, type Other.

3. In the Equation window, type DELTADT=DT-DTLOGR.

4. In the Description window, type Curve separation between DT and DTLOGR.

5. Click Next $>$ to proceed to the Assign Variables dialog box.

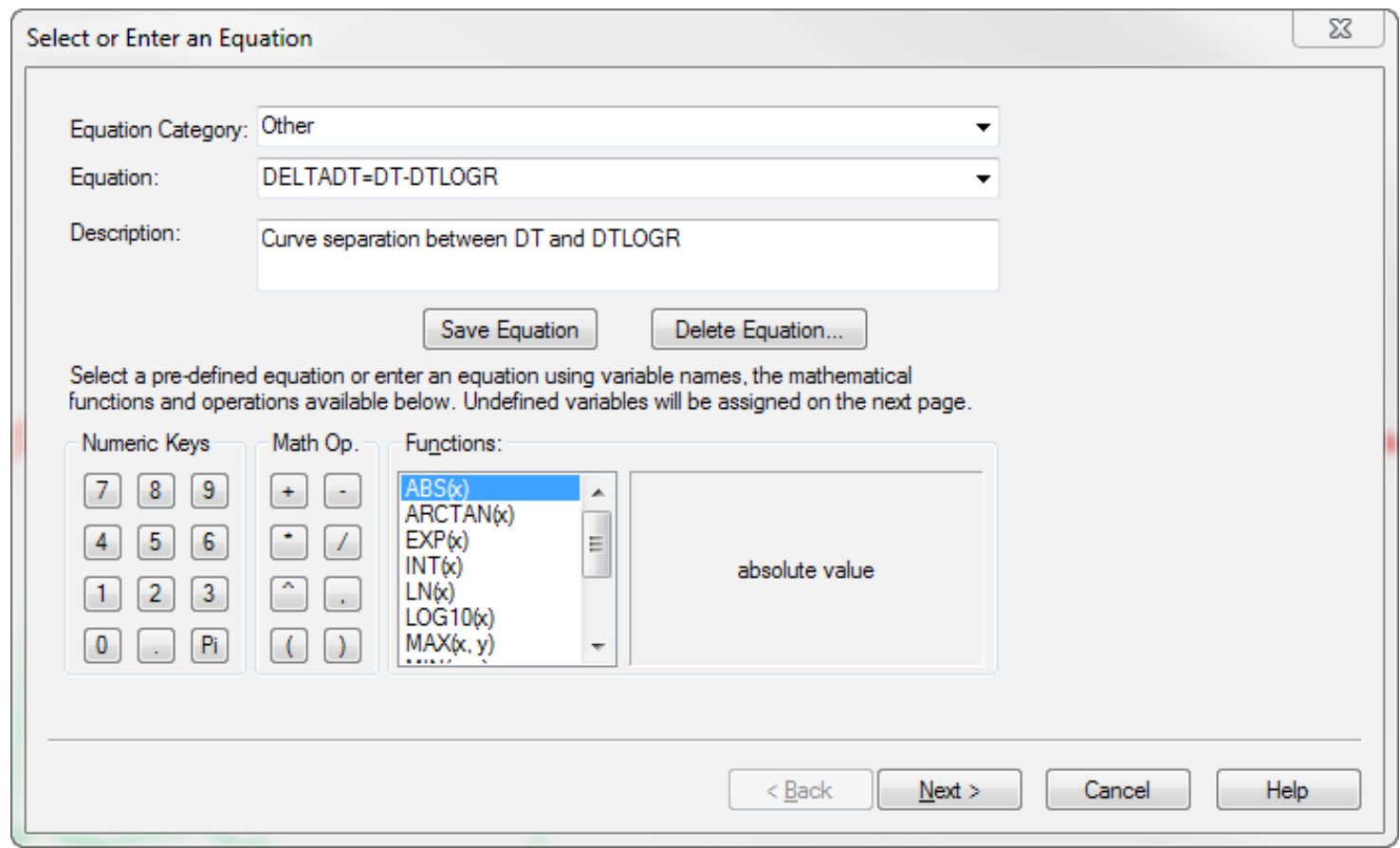


6. Assign DT to the DT log curve by selecting DT in the Select the Variable to Assign window, toggling on Log Curves, selecting DT from the drop-down menu, and clicking Assign.

7. Assign DTLOGR to the DTLOGR log curve by selecting DTLOGR in the Select the Variable to Assign window, toggling on Log Curves, selecting DTLOGR from the drop-down menu, and clicking Assign.

8. Click Next $>$ to proceed to the Depth Range Selection dialog box.

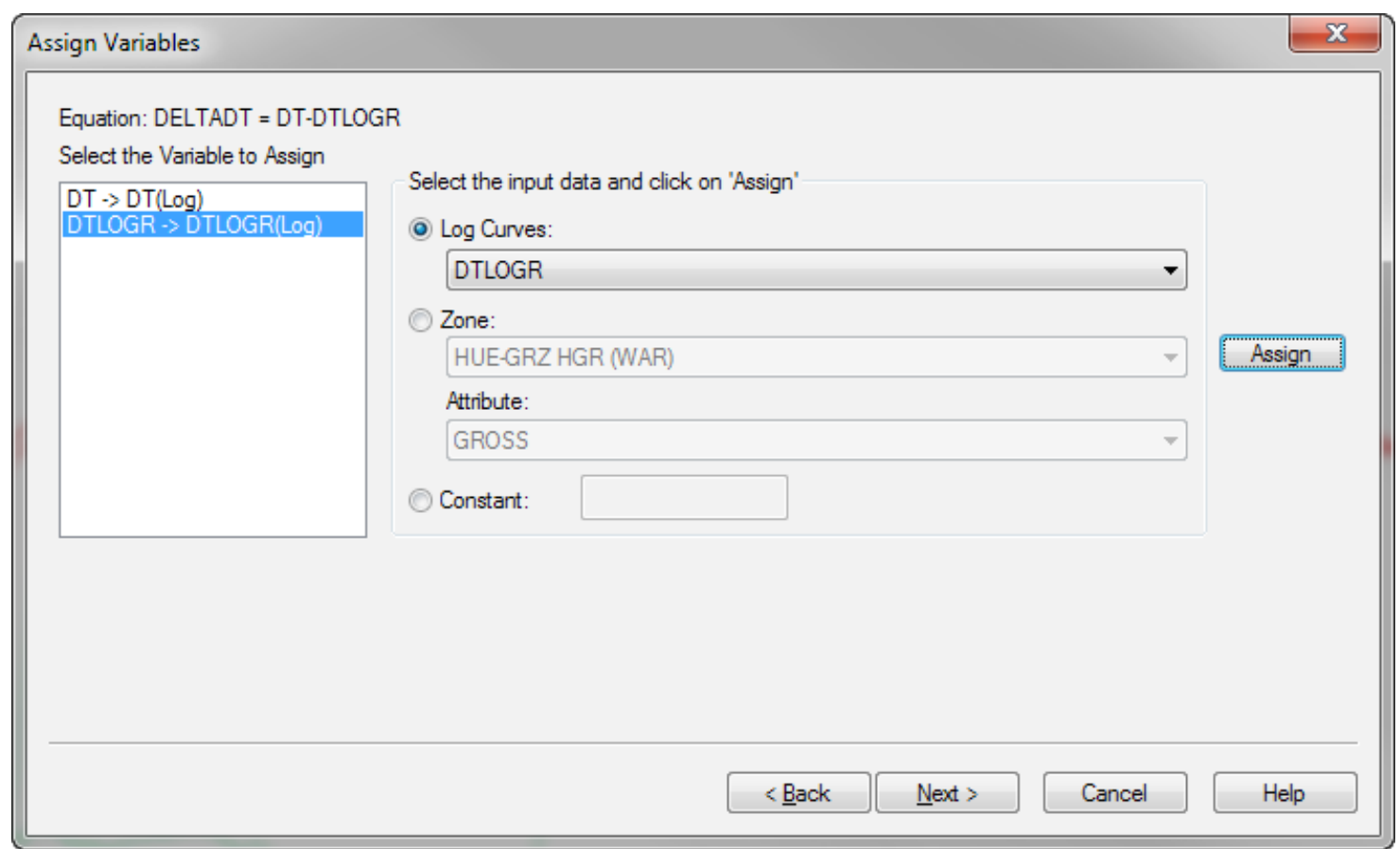


9. Toggle on by Zone Intervals and select the zone to be assessed for probable source rock potential from the drop-down menu.

10. Click Next $>$ to proceed to the Output dialog box.

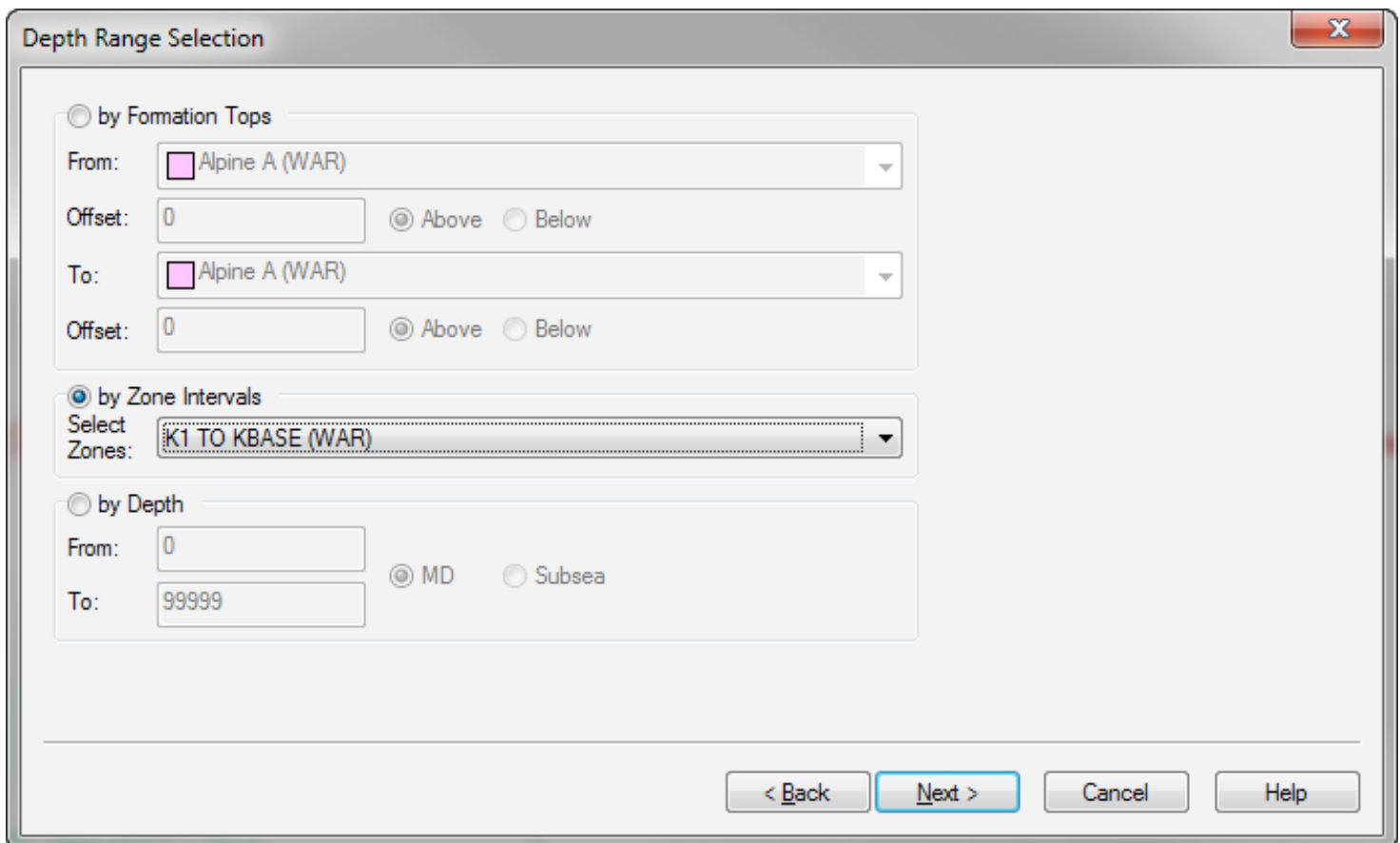

11. In the Output Log Curve Name window, type DELTADT.

12. In the Output Log Curve Type window, select Other from the drop-down menu.

13. Toggle on Create new log curve and replace existing curve.

14. Click Finish.

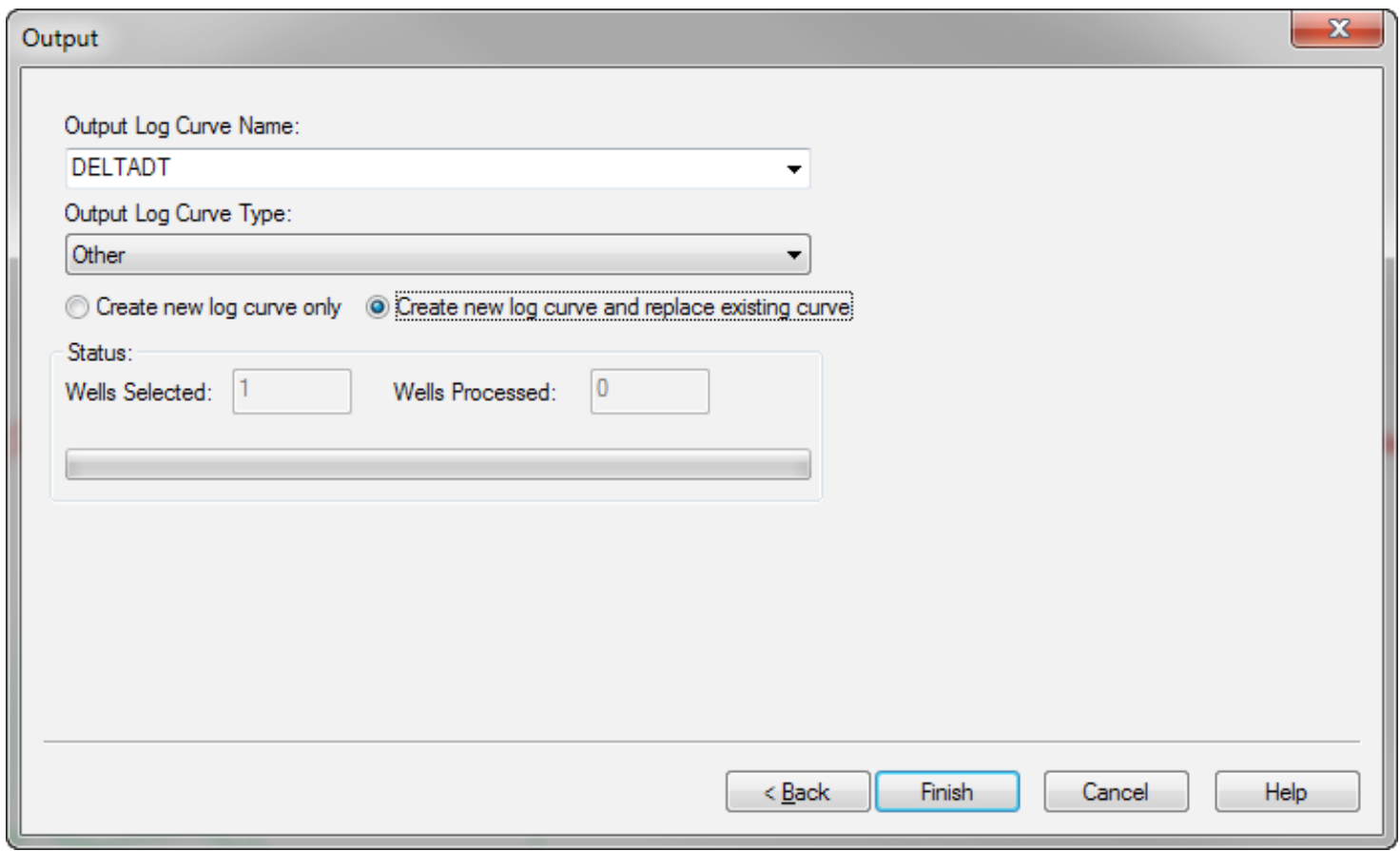




\section{Calculating $\Delta D T_{z}$}

Note: As of this publication, calculation of $\Delta D T_{z}$ entirely in IHS Kingdom ${ }^{\circledR}$ version 8.8 software is not possible. However, the key variables in the equation, and $h_{\text {net }}$, can be obtained using the Kingdom software.

\section{Finding $\Delta D T_{\bar{x}}$}

In order to restrict the calculation of $\Delta D T_{z}$ to positive $\Delta D T$ values:

1. From the Logs menu, select Calculations $\rightarrow$ If-Then-Else to proceed to the If-Then-Else for Log Curves dialog box.

2. Under IF, select DELTADT from the Log Curve Name drop-down menu, select GE (greater than or equal to) from the is drop-down menu, toggle on Constant and type $\mathbf{0}$.

3. Under THEN, toggle on Log Curve Name and select DELTADT from the drop-down menu.

4. Under ELSE, toggle on Missing (NULL).

5. Under Save As, type +DELTADT in the Log Curve Name window.

6. Click OK.

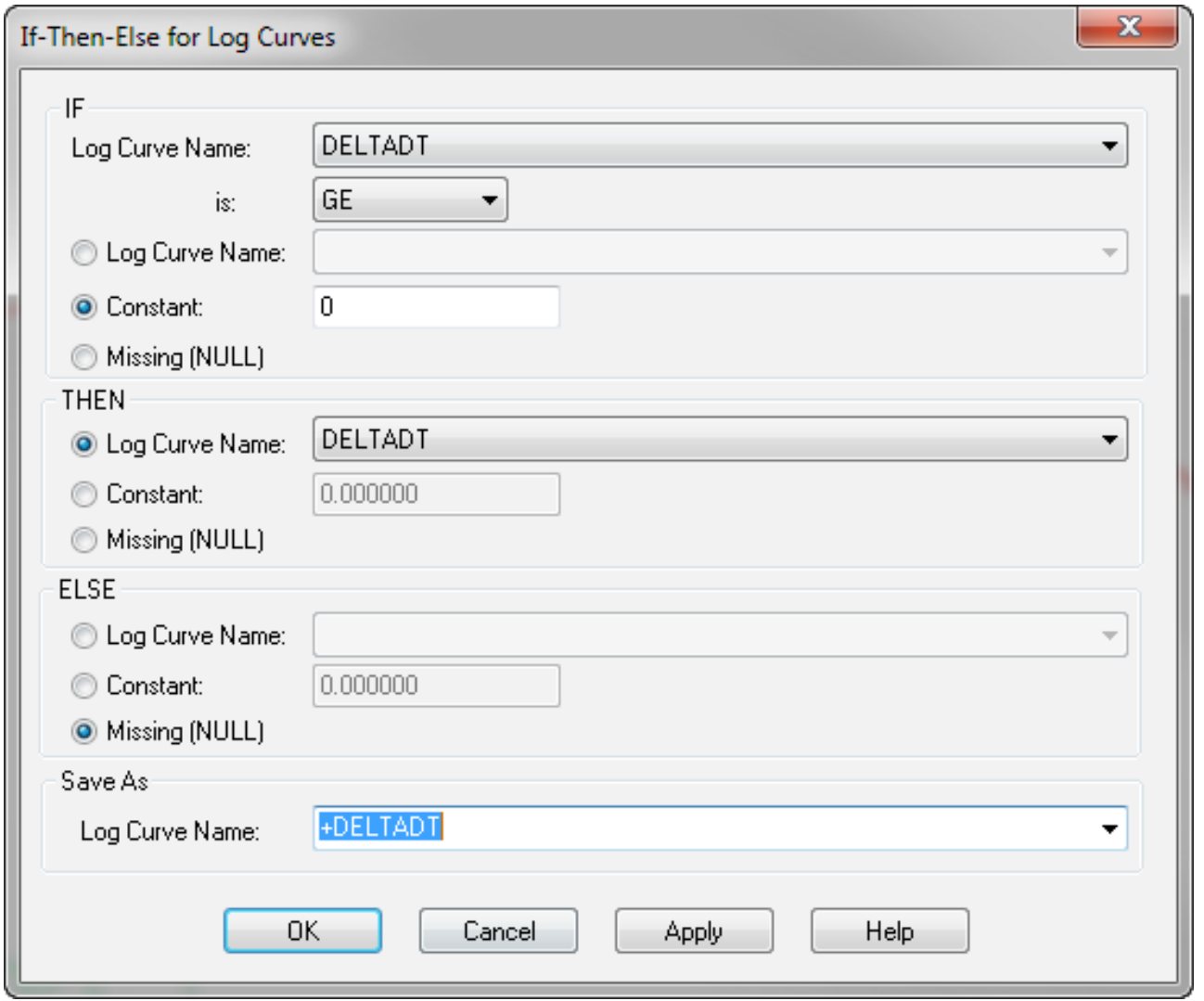


In order to further restrict the calculation of $\Delta D T_{z}$ to intervals containing at least 60 percent shale $\left(V_{s h} \geq 0.60\right)$ :

7. From the Logs menu, select Calculations $\rightarrow$ If-Then-Else to proceed to the If-Then-Else for Log Curves dialog box.

8. Under IF, select VSH from the Log Curve Name drop-down menu, select GE (greater than or equal to) from the is drop-down menu, toggle on Constant and type $\mathbf{0 . 6}$.

9. Under THEN, toggle on Log Curve Name and select +DELTADT from the drop-down menu.

10. Under ELSE, toggle on Missing (NULL).

11. Under Save As, type +DELTADT VSH $>0.6$ in the Log Curve Name window.

12. Click OK.

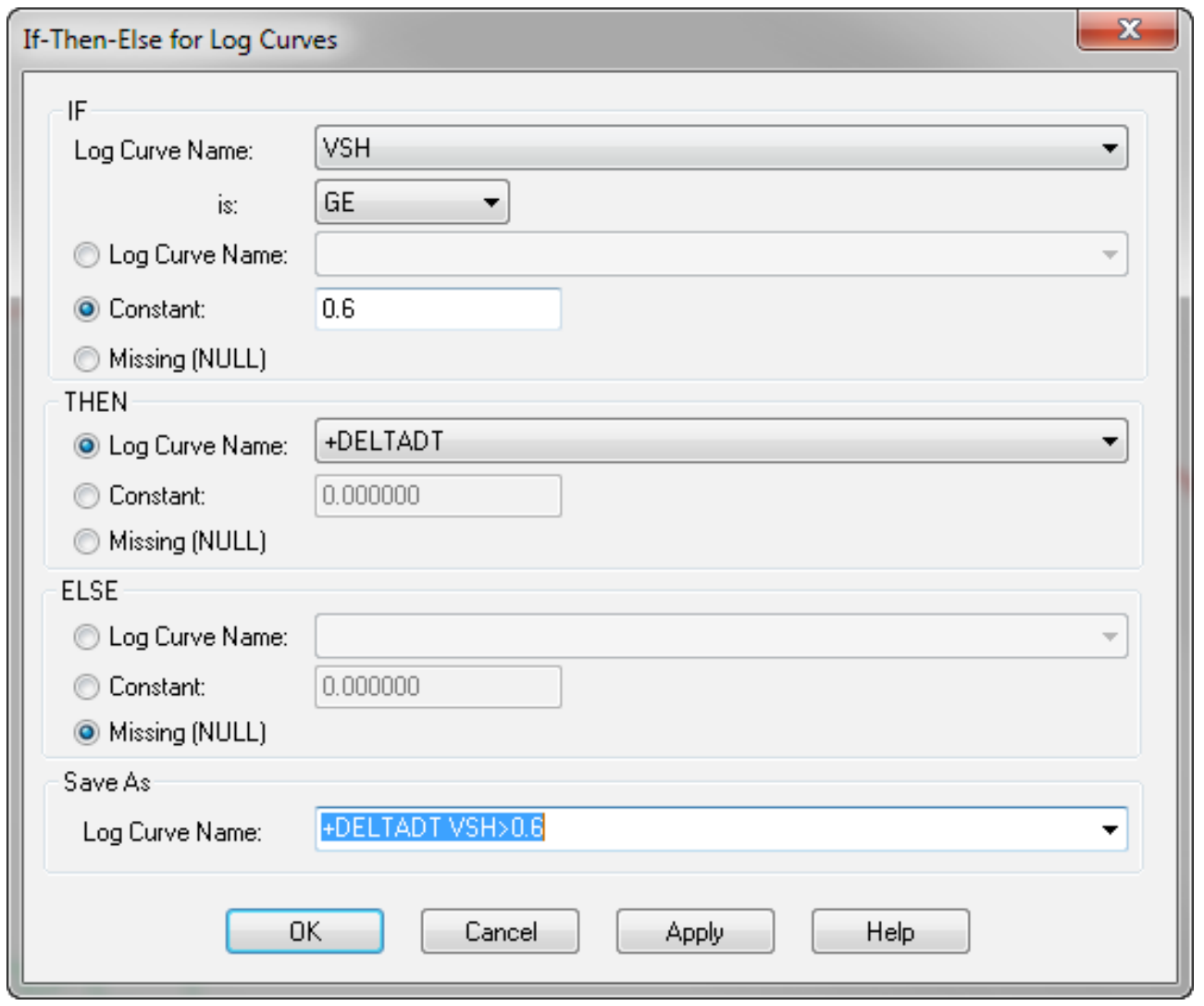


Finally, to find the mean $\triangle D T$ value $\left(\Delta D T_{\bar{x}}\right)$ :

13. From the Logs menu, select Calculations $\rightarrow$ Simple Statistics to proceed to the Log Curve Statistics dialog box.

14. Under Log Curves, select +DELTADT VSH>0.6.

15. Under Zones, select the zone to be assessed for probable source rock potential.

16. Click the check box next to Arithmetic Mean (AM) and type DDTAM.

17. Click OK.

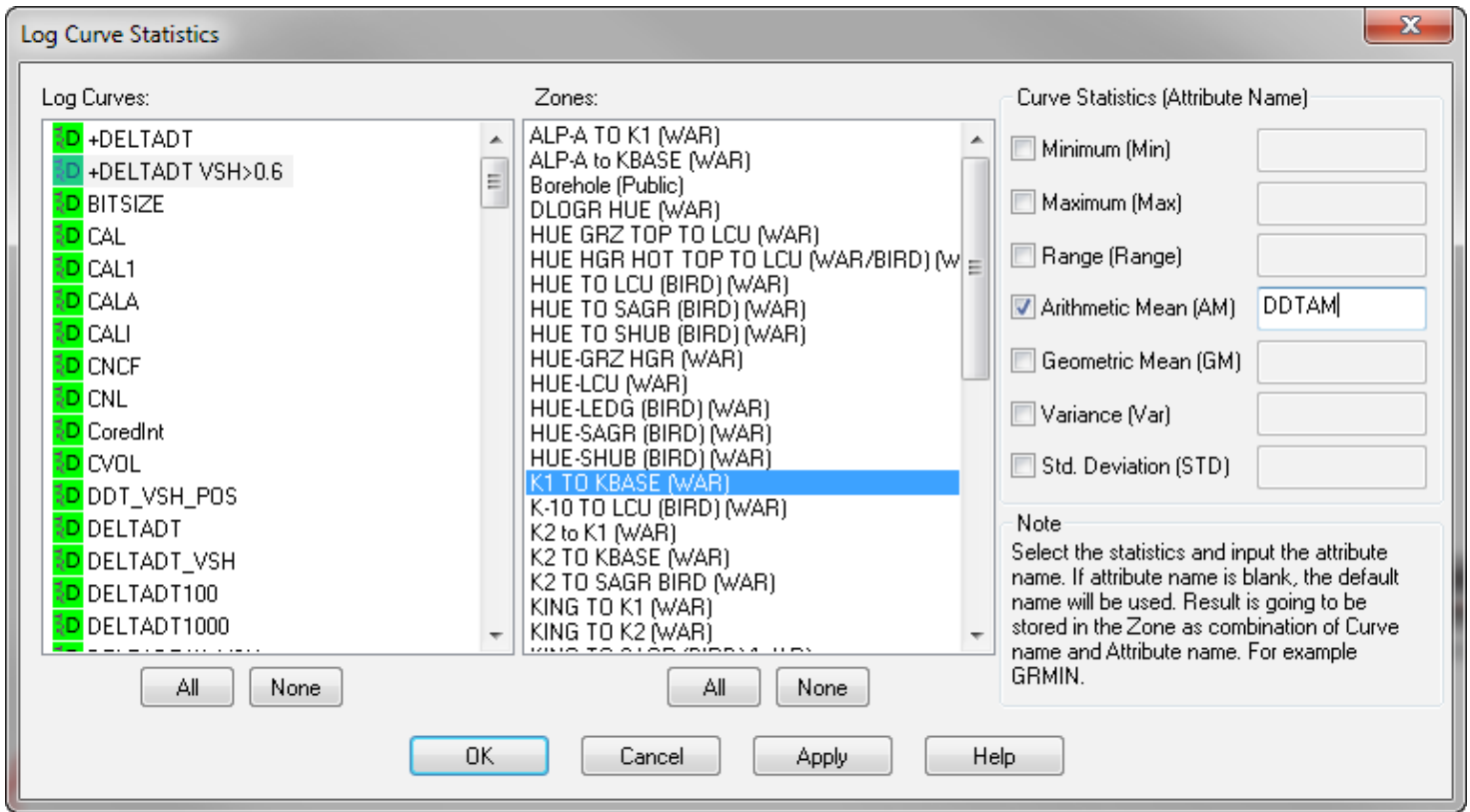


Finding $h_{\text {net }}$

1. From the Zones menu, select Zone Attribute Calculator to proceed to the Zone Attribute Calculator dialog box.

2. In the Attributes tab, under Attributes to Calculate, check the box next to Net and type HNET in the window.

3. Check the box next to Correct for TVD (Elev. Ref.).

4. Under Select One or More Zones, select the zone to be assessed for probable source rock potential.

5. Under Conditions, check the box next to Other, select the +DELTADT VSH $>\mathbf{0 . 6}$ log curve from the drop-down menu and choose the default values for Minimum and Maximum.

6. Click OK.

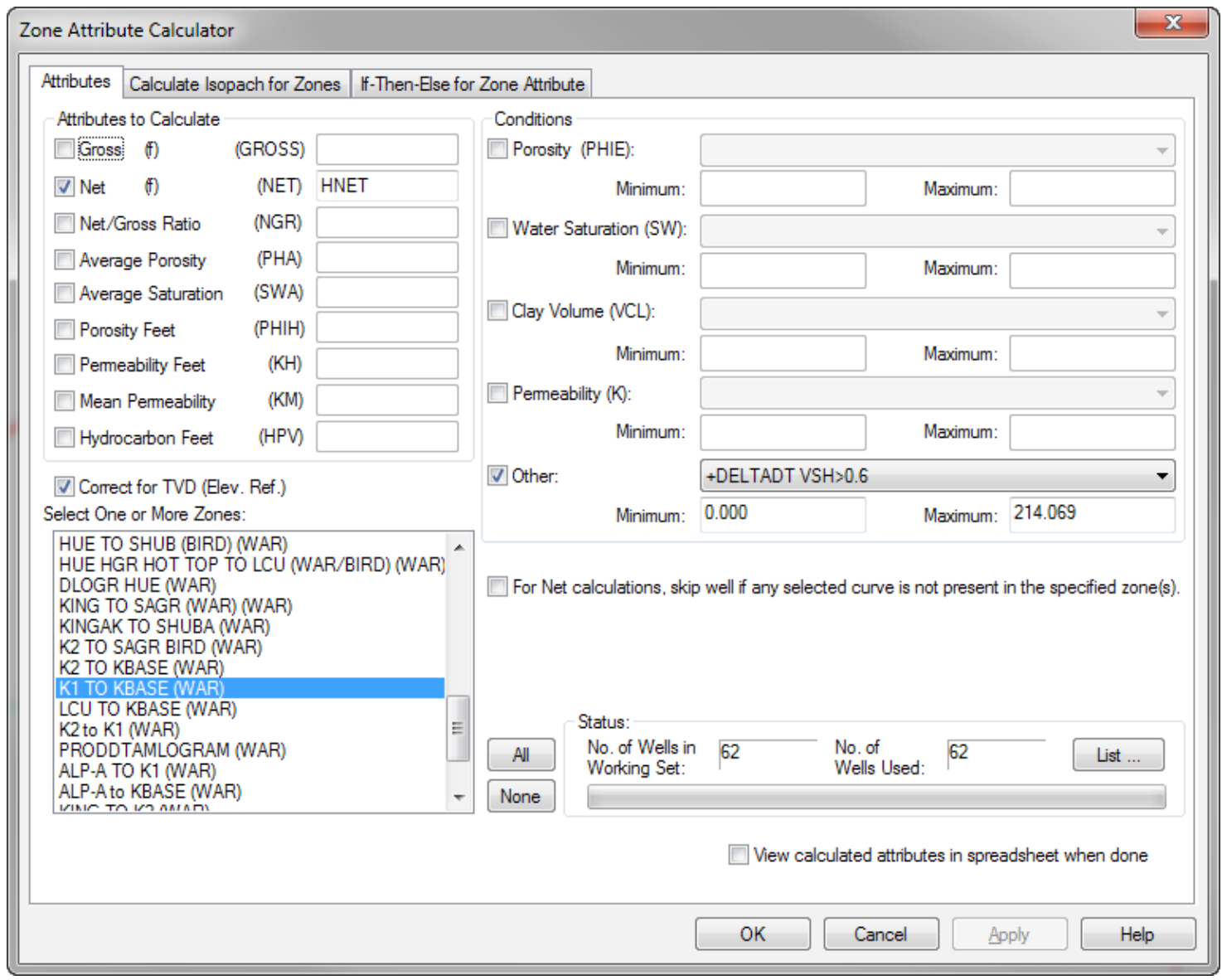




\section{Exporting the Spreadsheet}

The user can complete the calculation of $\Delta D T_{z}$ by exporting and $h_{\text {net }}$ to an Excel spreadsheet. To accomplish this:

1. From the Zones menu, select View Attribute Values by Zone to proceed to the Select Data for Spreadsheet dialog box.

2. Under Select Category, select Zone Information.

3. Under Zones, select the zone to be assessed for probable source rock potential from the drop-down menu.

4. Under Attributes, select DDTAM and HNET by clicking on each while holding down the 'ctrl' button.

5. Under Field, select Value.

6. Click $>$ to move your selections to the Selected Items window.

7. Click OK to proceed to the Spreadsheet.

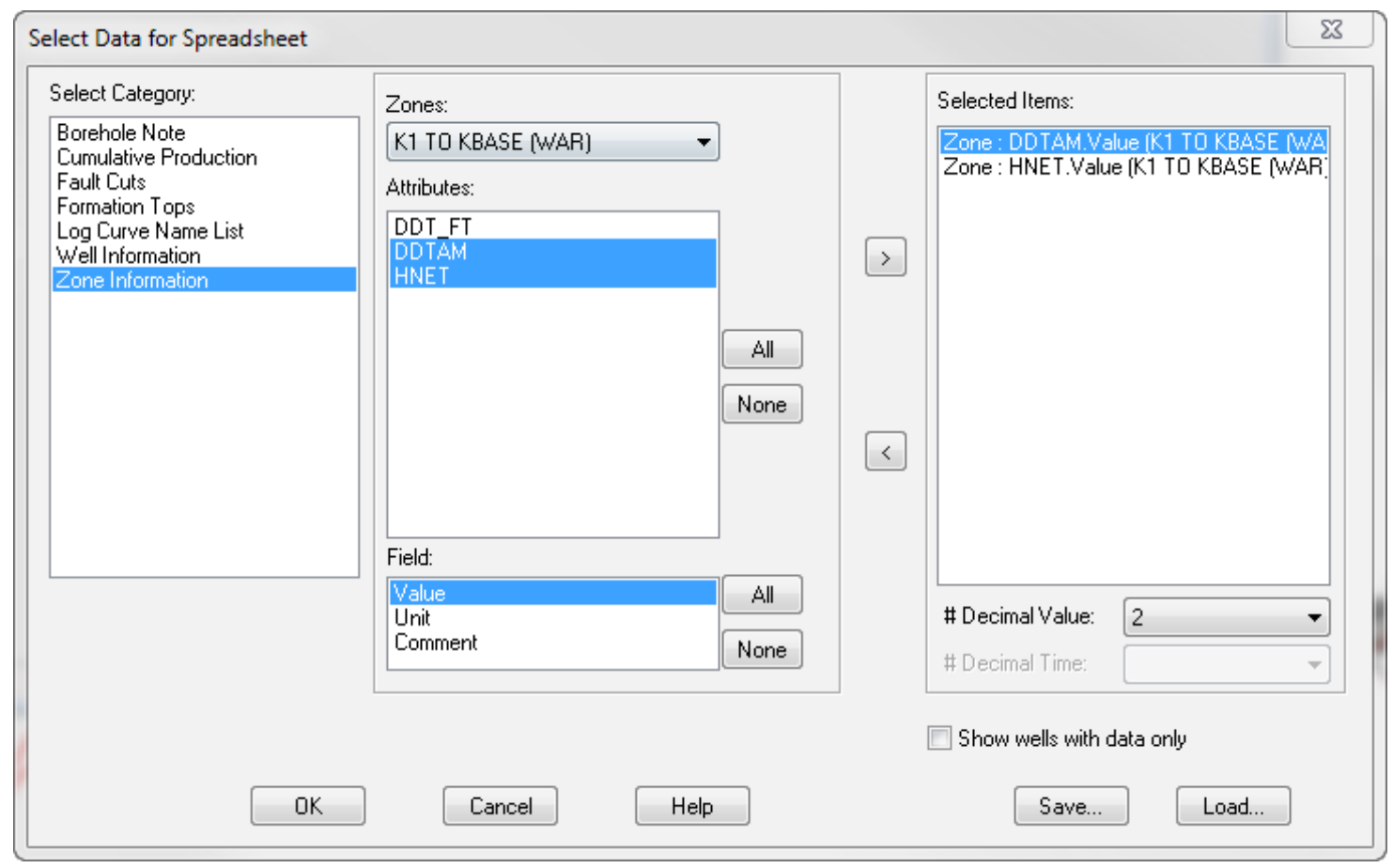


From the spreadsheet, the user can copy and paste the data into an Excel workbook.

\begin{tabular}{|c|c|c|c|c|c|c|c|}
\hline \multicolumn{6}{|c|}{ 書 Spreadsheet } & \multicolumn{2}{|c|}{\begin{tabular}{|l|l|}
$\square$ & 0 \\
\end{tabular}} \\
\hline \multicolumn{8}{|c|}{ 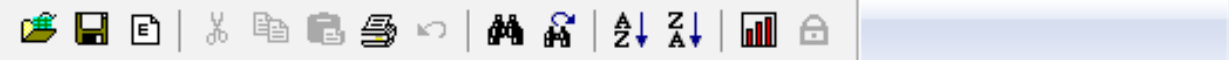 } \\
\hline & Well Name & Well Numb & Borehole N & UWI & DDTAM.Val & HNET.Value & $\Delta$ \\
\hline 1 & ABEL STATE & 1 & ABEL STATE & 50029202000000 & 7.60 & 198.00 & \multirow{31}{*}{$\equiv$} \\
\hline 2 & BEECHY POI & 1 & BEECHY POI & 50029200480000 & 10.59 & 181.00 & \\
\hline 3 & BELI UNT & 1 & BELI UNT & 50179200020000 & & & \\
\hline 4 & BURGLIN & $33-1$ & BURGLIN & 50029211060000 & 17.84 & 125.00 & \\
\hline 5 & BUSH FEDER & 1 & BUSH FEDER & 50223200040000 & 19.41 & 73.00 & \\
\hline 6 & COLVILLE D & 1 & COLVILLE D & 50103200380000 & 7.93 & 36.50 & \\
\hline 7 & COLVILLE D & 1 & COLVILLE D & 50103200020000 & 7.91 & 15.50 & \\
\hline 8 & COLVILLE S & 1 & COLVILLE S & 50103100020000 & 7.67 & 120.00 & \\
\hline 9 & E HARRISON & 1 & E HARRISON & 50703200010000 & 5.70 & 30.00 & \\
\hline 10 & EAST UGNU & 1 & EAST UGNU & 50029200520000 & 7.93 & 79.00 & \\
\hline 11 & GWYDYR B & 1 & GWYDYR B & 50029203960000 & 7.94 & 82.50 & \\
\hline 12 & HEMI SPRING & 1 & HEMI SPRING & 50029210560000 & 12.89 & 124.00 & \\
\hline 13 & HEMI SPRING & 3 & HEMI SPRING & 50029212850000 & 22.98 & 101.00 & \\
\hline 14 & HIGHLAND S & 1 & HIGHLAND S & 50029201990000 & 10.80 & 146.50 & \\
\hline 15 & IKPIKPUK TE & 1 & IKPIKPUK TE & 50279200040000 & 4.94 & 157.00 & \\
\hline 16 & INIGOK TEST & 1 & INIGOK TEST & 50279200030000 & 25.34 & 235.00 & \\
\hline 17 & JONES ISLA & 1 & JONES ISLA & 50029223190000 & 5.40 & 272.50 & \\
\hline 18 & KALUBIK CR & 1 & KALUBIK CR & 50103200010000 & 9.09 & 133.00 & \\
\hline 19 & KEMIK & 1 & KEMIK & 50223200060000 & 15.94 & 120.00 & \\
\hline 20 & KEMIK UNT & 2 & KEMIK UNT & 50223200130000 & 24.68 & 23.00 & \\
\hline 21 & KOKODA & 5 & KOKODA & 50279200120000 & 8.51 & 170.50 & \\
\hline 22 & KUGRUA TE & 1 & KUGRUA TE & 50163200020000 & 8.03 & 605.50 & \\
\hline 23 & KUPARUK & $9-11-12$ & KUPARUK & 50029201580000 & 13.92 & 118.50 & \\
\hline 24 & KUPARUK S & 1 & KUPARUK S & 50029200080000 & 24.34 & 87.50 & \\
\hline 25 & KUYANAK & 1 & KUYANAK & 50163200030000 & 2.91 & 58.00 & \\
\hline 26 & LONG ISLAN & 1 & LONG ISLAN & 50029210430000 & 5.54 & 76.00 & \\
\hline 27 & MILNE POINT & B-01 & MILNE POINT & 50029204900000 & 4.24 & 58.50 & \\
\hline 28 & MILNE POINT & $\mathrm{C}-1$ & MILNE POINT & 50029206630000 & 4.91 & 102.00 & \\
\hline 29 & MILNE PT UNI & 1 & MILNE PT UNI & 50029203760000 & 4.49 & 20.50 & \\
\hline 30 & N KUPARUK & $26-12-12$ & N KUPARUK & 50029200320000 & 7.45 & 130.50 & \\
\hline 31 & NFCHFI IK & 1 & NFCHFI IK & $5 \cap 1 \cap 32 n ก 2 n ก \cap ก \cap$ & $1 \cap 36$ & $2245 n$ & \\
\hline
\end{tabular}


Manuscript approved January 6, 2016

Prepared by the USGS Science Publishing Network Publishing Service Centers

Edited by Natalie Juda and David A. Shields, Reston Layout and illustrations by Caryl J. Wipperfurth, Raleigh

For more information concerning this report, contact:

Director, Eastern Energy Resources Science Center U.S. Geological Survey

12201 Sunrise Valley Drive

Mail Stop 956

Reston, VA 20192

http://energy.usgs.gov/

http://energy.usgs.gov/Generallnfo/ScienceCenters/Eastern.aspx 
